$\mathrm{DOI}$

http://dx.doi.org/10.1590/2236-463320161202

\title{
Ardras, minas e jejes, ou escravos de "primeira reputação": políticas africanas, tráfico negreiro e identidade étnica na Bahia do século XVIII
}

Ardras, Jejes and Minas, or slaves of "first reputation": African

Politics, Slave Trade and identity in Eighteenth-CenturySalvador,Brazil

Carlos da Silva Jr.

Wilberforce Institute for the study of Slaveryand Emancipation (WISE) University of Hull, Reino Unido carlos.ufba@gmail.com

\section{Resumo}

Em 1715, um viajante francês comentou que Salvador parecia uma "nova Guiné", devido à diversidade de origem dos escravos. Malgrado essa diversidade, Salvador guardava uma alta concentração de africanos escravizadosquecompartilhavamorigenssimilares. Estesescravosvinham principalmente do golfo do Benim, a segunda maior região escravista na África. $\mathrm{O}$ artigo visa discutir a presença dos falantes das línguas gbè (ardras, minas e jejes, principalmente) na Bahia durante o século XVIII. O trabalho de Luís Nicolau Parés, A formação do Candomblé, ilumina a presença de africanos da área gbè na Bahia setecentista. Ainda assim, há a necessidade de investigar as dinâmicas atlânticas que resultaram na deportação de gbè falantes para as Américas à luz de novas fontes. Ao explorar as conexões entre os eventos políticos no golfo do Benim e o tráfico baiano de escravos, o artigo também busca os números e origens dos exportados para a Bahia. Procuro combinar análises quantitativas acerca dos números do tráfico transatlântico de escravos, inventários post mortem e registros de batismo de modo a lançar luz sobre as vidas dos africanos ocidentais na Bahia do século XVIII.

\section{Abstract}

In 1715, a French observer commented that Salvador appeared to be a "New Guinea", due to the diversity of slave origins. However, in spite of this diversity, Salvador had a high concentration of enslaved Africans who shared similar origins. These slaves came primarily from the Bight of Benin, the second largest slaving region in Africa. The article aims to discuss the presence of gbe-speakers (ardras, minas and jejes, primarily) in Bahia in the eighteenth century. The work by Luís Nicolau Parés, A formação do candomblé,highlightsthepresenceofAfricansfromthegbè-speakingarea in eighteenth-century Bahia. Yet, it is necessary to investigate the Atlantic dynamics resulting in the deportation of gbe-speakers to the Americas on the light of new sources. In exploring the connections between the political events in the Bight of Benin and the Bahian slave trade, the article also seeks to discuss the numbers and origins of those exported to Bahia. I intend to combine quantitative analysis on the numbers of the transatlantic slave trade and the records in the probate and baptismal records in order to shed light on the lives of these West African groups in eighteenth-century Bahia. 
Por "área gbé" entendo a região setentrional do atual Togo, República do Benim e sudoeste da Nigéria, na qual vivem os povos conhecidos na bibliografia como aja, ewe, fon, entre outros. Recorro a PARÉS, Luís Nicolau. A formação do Candomblé: história e ritual da nação jeje na Bahia. Campinas: Editora da Unicamp, 2006, p. 14.

2

ELTIS, David; RICHARDSON, David. Atlas of the Transatlantic Slave Trade. New Haven e Londres: Yale University Press, 2010, mapa 80, p. 122, mapa 82, p. 124.

3

Sobre os mecanismos de obtenção de escravos na África Ocidental, consulte-se LOVEJOY, Paul E. Transformations in Slavery: A History of Slavery in Africa. $3^{\text {a }}$. ed. Nova York: Cambridge University Press, 2012; MANNING, Patrick. Slavery and African Life: Occidental, Oriental, and African Slave Trades. Nova York: Cambridge University Press, 1990; LAW, Robin. The Slave Coast of West Africa 1550-1750: The Impact of the Atlantic Slave Trade on an African Society. Oxford: Oxford University Press, 1991; THORNTON, John K. Africa and the Africans in the Making of the Atlantic World, 1400-1800. 2a. ed. ampliada. Nova York: Cambridge University Press, 1998; THORNTON, John K. Warfare in Atlantic Africa, 1500-1800. Londres: UCL Press, 1999; REID, Jonathan. WarfareinAfricanHistory.Cambridge:Cambridge University Press, 2013, entre outros.

4

A literatura sobre esse tema é extensa. Para alguns títulos, ver OLIVEIRA, Maria Inês Cortes de. Retrouver une identité: jeux sociaux des africains de Bahia (vers 1750-vers 1890). 1992. Tese (Doutorado em História). Université de Paris IV [Sorbonne], 1992; REIS, João José. Rebelião escrava no Brasil: a história do levante dos malês em 1835. $2^{\mathrm{a}}$ ed. revista e ampliada. São Paulo: Companhia das Letras, 2003, especialmente capítulo 10; SOARES, Mariza de Carvalho. Devotos da cor: identidade étnica, religiosidade e escravidão no Rio de Janeiro, século XVIII. Rio de Janeiro: Civilização Brasileira, 2000; SOARES, Carlos Eugênio Líbano; GOMES, Flávio dos Santos; FARIAS, Juliana Barreto. No labirinto das nações:africanos eidentidades no Rio de Janeiro, século XIX. Rio de Janeiro: Arquivo Nacional, 2005; PARÉS, Luís Nicolau. Op. Cit.; SILVEIRA, Renato da. Nações africanas no Brasil escravista: problemas teóricos e metodológicos. Afro-Ásia, N. 38 p. 245-301, 2008; SILVA JR., Carlos da, Identidades Afro-Atlânticas: Salvador, Século XVIII (1700-1750). Dissertação (Mestrado em História Social). Faculdade de Filosofia e Ciências Humanas, Universidade Federal da Bahia, Bahia, 2011, pp. 90-105, 182-228; GOMEZ, Michael A. Exchanging OurCountry Marks:Transformations of Identities in the Colonial and Antebellum South. Chapel Hill: University of North Carolina Press, 1998; KARASCH, Mary C. A vida dos escravos no Rio de Janeiro (1808-1850). São Paulo: Companhia das Letras, 2000, pp. 35-98; KARASCH, Mary C. 'Minha nação': identidades escravas no fim do Brasil Colonial. In: SILVA, Maria Beatriz Nizza da (org.). Brasil: colonização
Palavras-chave

Tráfico de escravos - Nações africanas - Gbè-falantes - Bahia - Golfo do Benim - Século XVIII

Keywords

Slave Trade -African Nations - Gbè Speakers - Bahia - Bight of Benin Eighteenth Century

O volume do tráfico entre a Bahia e o golfo do Benim fez de Salvador um dos principais locais de desembarque de africanos provenientes da área linguística gbè nas Américas no século XVIII. ${ }^{1}$ Cerca de $26,2 \%$ dos navios que traficaram em Uidá entre 1727 e 1863 tiveram Salvador como seu porto de origem, e 31,1\% das embarcações em Porto Novo também originaram-se da Bahia entre 1760 e $1850 .^{2}$ Este artigo explora as conexões entreestas duas partes do Atlântico. Eventos políticos no interiore no litoral do golfo do Benim resultaram na deportação em massa de milhares de africanos escravizados a bordo dos porões dos navios negreiros, muitos dos quais terminaram na Bahia. Por outro lado, a demanda dos senhores escravistas nas Américas fomentou processos de captura, intensificação de guerras, escravização por dívidas, sequestros, punições judiciais, entre outros mecanismos de escravização na África Ocidental. ${ }^{3}$

Aos recém-chegados atribuía-se o nome de umas das diversas "nações"africanas, categoriasétnicas criadas pelotráfico negreiro para designar a escravaria da África. Assim, denominava-se pelo rótulo de "nação" osgruposétnicosafricanosreconstituídosnadiáspora. ${ }^{4}$ Os afro-ocidentais ficaram conhecidos no Brasil principalmente pelos termos ardras, minas e, mais tarde, jejes. Outros nações de matriz gbè desempenharam papel importante na escravidão africana em outras regiões da América portuguesa, como os mahis, savalus, agonlis, couras/couranos etc. ${ }^{5}$ Algumas destaspodemserencontradasnadocumentaçãobaiana, inclusive.Todavia, há inegável hegemonia dos minas, ardras e jejes, nações que coexistiam e amiúde se confundiam na babel africana da Bahia.

Ao focar principalmente-embora não exclusivamente-nestes três grupos da África Ocidental, esseartigo visa entenderas dinâmicas nos portos negreiros da Costa da Mina que possibilitaram a exportação de milhares de cativos falantes de gbè de diferentes grupos étnicos daquela região - aïzo, hula, hueda, fon, mahi, gun, ewe etc. - ao longo do século XVIII. ${ }^{6}$ Outrossim, buscoaindaentenderapreferênciadossenhoresdeescravosda Bahia por africanos ocidentais, malgrado suas frequentes reclamações sobreoperfil rebeldedestesescravos.Emboraoartigoapresentedadossobre o século XVIII como um todo, analisarei com mais vagar a primeira metade do setecentos, período em que o termo arda ainda era bastante popular, convivendo e se intercambiando com as denominações jeje e mina.

Inicialmente, esse texto explora certas particularidades sobre a escolha dos cativos destinados à Bahia. Há evidência inequívoca do interesse dos traficantes luso-baianos por escravos da mesma área cultural. Dito de outro modo, existia uma demanda específica por gente da Costa da Mina entre os senhores e comerciantes baianos. As razões serão discutidas ao longo do texto, mas isso indica o alto grau organizativo da empresa traficante na Bahia do século XVIII. O artigo enfoca na pertença étnica, 
e escravidão. Rio de Janeiro: Nova Fronteira, 2000, p. 27-41; LOVEJOY, Paul E. (org.). Identity in the Shadow of Slavery. Londres: Continuum 2000; LOVEJOY, Paul E.; TROTMAN, David V. (orgs.). Trans-Atlantic Dimensions of Ethnicity in the African Diaspora. Londres: Continuum Press, 2003;HALL, Gwendolyn Midlo. Slaveryand African Ethnicities in the Americas: Restoring the Links. Chapel Hill: University of North Carolina Press, 2005; THORNTON, John K. Africa and the Africans. Op. Cit., pp. 184-92.

5

SOARES, Mariza de Carvalho. Op. Cit.; MAIA, Moacir Rodrigo de Castro. O apadrinhamento de africanos em Minas Colonial: o (re)encontro na América (Mariana, 1715-1750). Afro-Ásia, 36, pp. 39-80, 2007.

6

O vocábulo "gbè" (pronuncia-se "bê") significa "língua" na maioria das 51 línguas dessa região. Ainda que não seja um termo de autoidentificação, esse vocábulo não privilegia um grupo em detrimento de outros. Sobre essa questão, ver CAPO, Hounkpati B.C. Comparative Phonology of Gbe. Berlin e Nova York: Foris Publications, 1991; PARÉS, Luís Nicolau. Op. Cit., p. 14,34

7

ELTIS, David; RICHARDSON, David. Op. Cit. p. 39, tabela 3. Dados atualizados sobre os números do tráfico atlântico podem ser conferidos em ELTIS, David;BEHRENDT,Stephen;RICHARDSON,David; FLORENTINO,Manolo.Voyages:TheTransatlantic Slave Trade Database (Voyages). Disponível em: <http://www.slavevoyages.org/tast/database/ search.faces.>

8

O trabalho de referência é VERGER, Pierre. Fluxo e refluxo do tráfico de escravos entre o Golfo de BenineaBahiadeTodososSantos(dosséculosXVII a XIX). Salvador: Ed. Corrupio, 4ª ed., 2002 [1968]. As relações Bahia-Costa da Mina foram também estudadasporRIBEIRO,AlexandreVieira.Otráfico atlântico de escravos e a praça mercantil de Salvador, c. 1680-c. 1830. Dissertação (Mestrado em História Social). Universidade Federal do Rio deJaneiro, RiodeJaneiro, 2005.Sobreaexpressão "metrópole da Costa da Mina", ver ALENCASTRO, LuizFelipede.DesagravodePernambucoeaglória do Brasil: a obra de Evaldo Cabral de Mello. In: SCHWARCZ, Lilia Moritz (org.). Leituras críticas sobre Evaldo Cabral de Mello. Belo Horizonte: Editora da UFMG/ São Paulo: Editora Fundação Perseu Abramo, 2008, p. 43. ALENCASTRO, Luiz Felipede.Otrato dos viventes:formação do Brasil no Atlântico Sul, séculos XVI e XVII. São Paulo: Companhia das Letras, 2000, pp. 29, 63, 353.

9

LABAT, Jean-Baptiste. Voyages du Chevalier des Marchais en Guinée, isles voisines et à Cayenne, fait em 1725, 1726 et 1727. Paris: Chez Saugrain, Quay de Gefvres, à la Croix Blanche, 1730, vol. ii, p. 125.

10

PARÉS, Luís Nicolau. Op. Cit., p. 44. aspectodeverasimportante, pois demonstracomoobackgroundafricano (principalmente a língua) desempenhou um papel crítico na organização das comunidades africanas na diáspora.

Emseguida,esseartigoexaminarábrevementeotráficonessaporção da África Ocidental durante os séculos XVII e XVIII. Dinâmicas políticas na região resultaram na exportação de cativos de grupos étnicos do litoral e do interior da Costa da Mina para a Bahia. Compreender as disputas entre as principais entidades políticas da região pelo acesso ao mercado atlântico de escravos iluminará as diferentes fases do tráfico para a Bahia. $O$ artigo também lançaráluz sobreo papel dos diferentes grupos envolvidos neste comércio, seja como escravistas ou como escravizados. Questões sobre a legalidade da escravidão de súditos e as fronteiras escravistas no golfo do Benim são cruciais para a interpretação da presença afro-ocidental nos portos escravistas nas Américas em geral, e na Bahia em particular.

Porfim, discuto o volume do tráfico atlântico do golfo do Benim para as Américas e a participação baiana nesse comércio. Sabe-se que Salvador foi o segundo maior terminal escravista das Américas durante a vigência dotráficonegreiro,sendosuperadoapenaspeloRiodeJaneironessainglórialista. ${ }^{7}$ A Bahia estabeleceuvínculos políticoseculturais duradouros com o golfo do Benim, convertendoSalvador em "metrópole"da Costa da Mina no setecentos, nas palavras de Luiz Felipe de Alencastro. ${ }^{8}$ Nesse sentido, a demografia do tráfico e da escravidão africana na Bahia (baseada em inventários postmortem, registros debatismos) confirmamafortepresença dos negreiros luso-brasileiros no litoral da Costa da Mina. Mais ainda, informa o peso do tráfico para a Bahia no conjunto do tráfico transatlântico e na porção do tráfico no golfo do Benim.

Ao enfocar nos africanos ocidentais oriundos da Costa da Mina, esse artigo visa contribuir com o debate sobre a diáspora gbè na Bahia no séculoXVIII.Argumentoqueaexpressivapresençadosafricanosdessaárea cultural na Bahia respondetambémaos interesses dos senhoresetraficantes em cativos dessa região. A historiografia há muito enfatiza o aspecto comercial (a oferta elástica de tabaco) como decisiva na consolidação dos laços entre a Bahia e o golfo do Benim. Em que pese a importância dessa mercadoria no conjunto de trocas comerciais entre as duas regiões, uma gramática cultural comum entre os africanos dos diversos grupos gbè desempenhoupapelcríticonaescolhadosportosafricanos detráficopelos comerciantes baianos. Ao analisar esses dois fatores, entende-se porquea Bahiatornou-seoprincipaldestinodosdeportadosdogolfodoBenimpara as Américas durante a vigência do comércio atlântico de escravos.

\section{Do significado dos termos}

Antes de passar para o tema, porém, é preciso familiarizar o leitor com os termos ardra, mina e jeje. Os ardas (ardras, aladas) denominavam aqueles exportados pelo reino de Alada, através de seus principais portos, Ofra e Jakin, e não deveriam ser confundidos com os habitantes de Alada, ensina o padre Labat. ${ }^{9}$ De fato, informa Luís Nicolau Parés, "[ar]da designava o centro comercial onde os escravos tinham sido vendidos aos portugueses".10Tal nome é mencionado já no século XVII, em partes da América hispânica; em meio às guerras no Brasil holandês, Henrique Dias citou os "Ardas" como uma das nações do seu batalhão, como veremos adiante. $O$ 
Ibidem, p. 67, argumenta que o termo ardra foi suplantadopeladenominaçãojeje,correspondente ao declínio de Alada e à ascensão de Uidá no comércio da Costa da Mina. Entretanto, a consolidação do termo jeje em Salvador ocorreu apenas na segunda metade do século XVIII.

\section{2}

Para um debate sobre o termo"mina", ver HALL, Gwendolyn Midlo. African Ethnicities and the Meanings of'Mina'. In: LOVEJOY, Paul;TROTMAN, David V. (orgs.). Op. Cit., p. 65; LAW, Robin. Etnias de africanos na diáspora: novas considerações sobre os significados do termo'mina'.Tempo, Rio de Janeiro, $n^{\circ} 20$, pp. 109-31, 2005

13

RODRIGUES, Raimundo Nina. Os africanos no Brasil. São Paulo: Editora Nacional; Brasília: Editora da Universidade de Brasília, 1982, pp. 103, 105.

14

VERGER, Pierre. Notas sobre o culto aos orixás e voduns na Bahia de Todos os Santos, no Brasil, e na Antiga Costa dos Escravos, na África. São Paulo: Editora da Universidade de São Paulo, 2000, p. 23, n. 12

15

COSTA LIMA, Vivaldo da. A família de Santo nos candomblés jeje-nagôs da Bahia: um estudo das relações intragrupais. Salvador: Corrupio, 2003, pp. 22-3; OLIVEIRA, Maria Inês Cortes de. Quem eram os "Negros da Guiné"? A origem dos africanos na Bahia. Afro-Ásia, Salvador, n 29/30 (1997), pp. 70-1.

16

MATORY, J. Lorand. Jeje: repensando nações e transnacionalismo, Mana, n 5, abr. 1999, pp. 62-3.

17

PARÉS, Luís Nicolau. Op. Cit. pp. 47-51;

PARÉS, Luís Nicolau. Ethnic Religious Modes of Identificaton among the Gbe-Speaking People in Eighteenth and Nineteenth Century Brazil. In: SANSONE, Lívio; SOUMONNI, Elisée; BARRY, Boubacar (orgs.). Africa, Brazil and the Construction of Trans Atlantic Black Identities. Trenton: Africa World Press, 2008, pp. 184-85.

18

PARÉS, Luís Nicolau. A formação do Candomblé. Op. Cit. p. 47; SILVA JR., Carlos da. Identidades Afro-Atlânticas. Op. Cit., p. 198

19

LOHSE, Kent Russell. Africans and Their Descendants in Colonial Costa Rica, 1600-1750. Tese (Doutorado em História). University ofTexas at Austin, 2005, pp. 68, 130, n. 56.

20

Arquivo Público do Estado da Bahia (APEB), Seção Judiciário (SJ), 03/1416/1885/02, Inventário postmortem deVentura FerreiraVivas(1720).Grifomeu.

21

LABAT, Jean-Baptiste. Op. Cit., vol. ii, p. 125. termoardra perdeforça na documentação baiana àmedidaqueo designativo mina se populariza, a partir das primeiras décadas do século XVIII. ${ }^{11}$

O termo mina, por sua vez, servia como uma espécie de "guarda chuva"étnico englobando os africanos oriundos da Costa da Mina, termo português que define, grosso modo, as antigas costas do Ouroe dos Escravos. No caso baiano, veremos a seguir, a maioria esmagadora dos minas na Bahia setecentista era oriundo da área gbè, mas certamente alguns africanos escravizados da Costa do Ouro podem ter terminado a travessia atlântica na Bahia, via negreiros baianos que tocavam o litoral da Costa do Ouro ao longo do século XVIII. ${ }^{12}$

Concluo com os jejes, cuja origem ainda está em disputa. A história do debate acerca do termo vêm de longa data; historiadores e antropólogostentamexplicarseusignificadodesdeNinaRodrigues, pelomenos. Este o associou aos gen e ewe, na fronteira com oTogo. ${ }^{13}$ Pierre Verger, por sua vez, sugeriu ser uma deformação de adja. ${ }^{14}$ Vivaldo da Costa Lima argumentou que a expressão designava os "grupos étnicos do Baixo Daomé especialmente os fon e os gu", e acreditava que o termo evoluiu do iorubá ajèji, "estrangeiro", em referência à migração fon - na verdade aïzo - vinda do leste, hipótese seguida por Maria Inês Oliveira. ${ }^{15}$ Malgrado suas diferentes interpretações, todos concordam que o etnônimo surgiu na África, sendo posteriormente transportado para o Brasil.

A hipótese de James Lorand Matory, por sua vez, explica que dado a ausência da denominação na África antes de 1864, segundo suas pesquisas, o termo deve ter surgido no Brasil e chegado à África somente na década de $1860 .{ }^{16}$ Nicolau Parés sustenta, no entanto, que o termo deriva de idjé, povo localizado entre Pobé e Ketu, ao norte de Porto Novo. Sua localização entre os reinos de Alada, Benim e Daomé os tornou vítimas de raziase expedições paracaptura deescravos. Aexpansãodaomeana parao litoral nas primeiras décadas do século XVIII refletiria o aparecimento das primeiras menções ao termo na documentação. ${ }^{17}$ Dito de outro modo, a denominação jeje, originalmente um etnônimo local, graças à sua apropriação pelos traficantes de escravos eatravés de mudanças fonéticas e de abrangência na diáspora, passou a designar os escravos gbè falantes.

O primeiro registro jeje na Bahia - e provavelmente nas Américas data de 1711 , no Recôncavo baiano. ${ }^{18}$ Para Salvador, a primeira menção é de 1720, veremos no parágrafo seguinte. Diferente de outras denominações encontradas em outras áreas do mundo atlântico, jeje parece ter sido um termo quase exclusivo da Bahia. Não há evidência documental de seu uso no Haiti, Cuba, Trinidad ou outras áreas da Américas que receberam escravos da área gbè. A exceção encontra-se na Costa Rica, onde Russell Lohseidentificouumafricanoyjéouejéem 1719, oquepoderiacorresponder ao etnônimo jeje. ${ }^{19}$

Embora o termo jeje possa resultar do nome de um grupo étnico, o nome pode ainda derivar da prática da escarificação na área gbè daqueles tempos. O inventário post mortem do mestre de campo Ventura Ferreira Vivas, realizado em Salvador, em 1720, faz referência a um "molecão novo do gentio da Mina com três geges em cada uma das faces".20 Esta é uma menção às marcas étnicas ou escarificações, um dos emblemas de identidade entre alguns grupos africanos. Em Alada e Uidá os sinais eram inscritos ainda em tenra idade, em "crianças de peito", segundo o padre Labat. ${ }^{21}$ O jovem africano trazia na face os mesmos sinais diacríticos de um grupo de pessoas que, mais tarde, seriam provavelmente identificados na 
Para a marca entre os iorubás, consultar JOHNSON, Samuel. The History of the Yorubas: From the Earliest Times to the Beginning of the British Protectorate. Lagos: CMS (Nigeria) Bookshop, 1956, p. 106. Ver ainda REIS, João José. Op. Cit., p. 313.

\section{3}

VERGER, Pierre. Op. Cit., p. 37.

\section{4}

LAW, Robin. The Slave Coast. Op. Cit., p. 13.
Bahiacomojejes. Emoutras palavras, algumas nações africanas podiamser identificadas pelassuasescarificações, como pareceteracontecidocomos jejes, sobretudo no início do tráfico desses povos. Outra hipótese é que o termo jeje fosse o nome dessas marcas entre os falantes de gbè falantes entre os ioruba-falantes a marca mais conhecida era o Abaja - ou mesmo entre um pequeno grupo gbè. ${ }^{22} \mathrm{O}$ debate ainda encontra-se em aberto.

Uma última palavra sobre termos. Ao longo desse artigo, usarei as expressões "Costa da Mina"e "Golfo do Benim" como sinônimos. Essa escolha não é fortuita. Pierre Verger chamava de Costa da Mina a parte do golfo do Benim situada entre o rio Volta e Cotonu, e recorria aos termos Golfo ou Baía do Benin quando tratava daquela parte da costa que incluía a região a leste atéo rio Lagos. ${ }^{23}$ Definição semelhanteéutilizada para precisar os limites da área conhecida entre os traficantes ingleses como Costa dos Escravos, que compreendia o sudeste de Gana, o Togo, Benim e o sudoeste da Nigéria. ${ }^{24}$

MAPA I: COSTA DA MINA, FINAL DO SÉCULO XVII

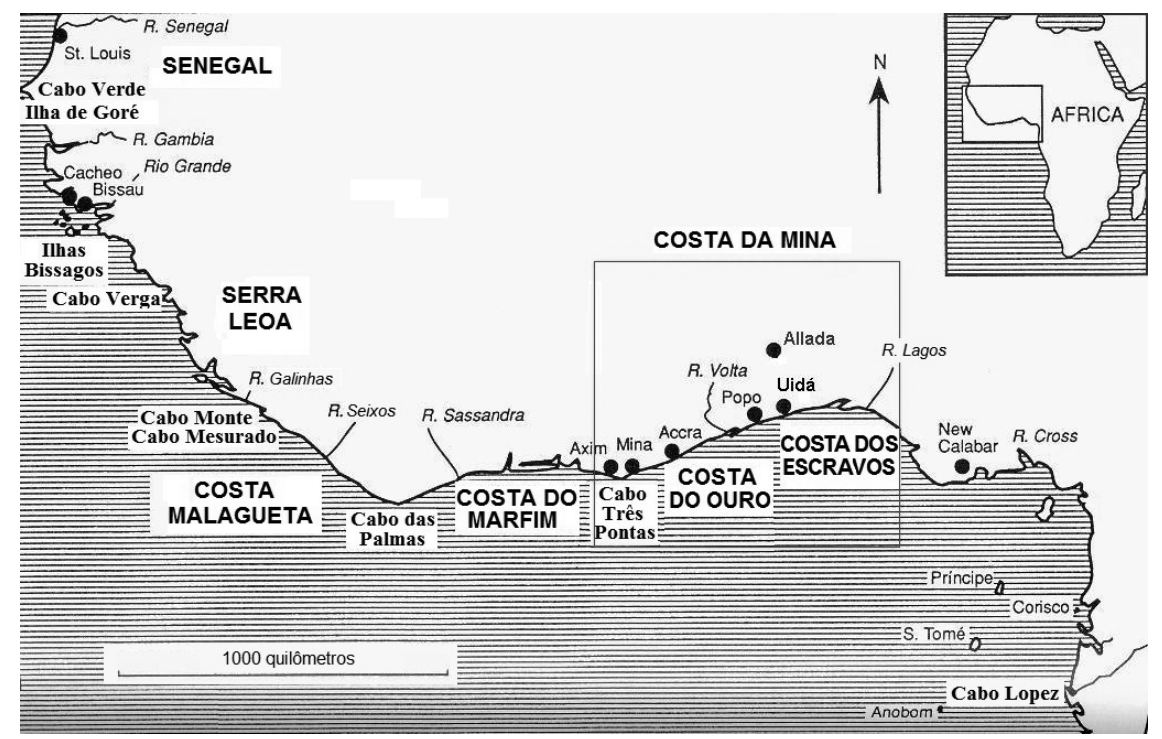

Adaptado de BARBOT, Jean. Barbot on Guinea:The Writings of Jean Barbot on West Africa, 1678-1712 (organização de LAW, Robin; JONES, Adam; HAIR, Paul). Londres: Hakluyt Society, 1992. Extraído de PARÉS, Luís Nicolau (org.). Práticas religiosas na Costa da Mina. Umasistematizaçãodasfonteseuropeiaspré-coloniais, 1600-1730.Disponívelem:<http:// www.costadamina.ufba.br/>. Acesso em: 07 mar. 2016.

A Costa da Mina incluía, portanto, os limites das antigas Costa do Ouro e dos Escravos. Entretanto, fontes europeias dos séculos XVII e XVIII atestam que os limites da Costa da Mina estendiam-se desde o Castelo de São Jorge da Mina (atual Gana) até Lagos (atual Nigéria). Eventualmente, até mesmo portos mais ocidentais, como Cabo Lahu (atual Costa do Marfim), faziam parte dos limites da Costa da Mina. ${ }^{25}$ Malgrado o vago registro "Costa da Mina" como o destino da maioria dos negreiros baianos em direção à África nos séculos XVIII e XIX (até 1815, pelo menos), sabe-se que os traficantes sediados na Bahia faziam seus negócios principalmente - mas não somente - nos portos de Uidá, Porto Novo, Badagrie Lagos, que faziam parte do golfo do Benim. Portanto, quando não houver indicações mais precisas, usarei "Costa da Mina" e "Golfo do Benim" para me referir ao tráfico luso-baiano naquela porção da África Ocidental. 
Padrões de escolhas por escravos na babel africana setecentista: interesses econômicos e aspectos culturais

26

GONSALVES de MELLO, José Antônio. Fontes para a História do Brasil Holandês (FHBH), vol. I. Recife: s.e., 1981, pp. 186-87 apud ALENCASTRO, Luiz Felipe. O trato dos viventes. Op. Cit., p. 150

\section{7}

ANTONIL, André João. Cultura e Opulência do Brasil por suas Drogas e Minas [1711]. Introdução e notas por SILVA, Andrée Mansuy Diniz. São Paulo: Editora da Universidade de São Paulo, 2007, Livro 1, capítulo IX, p. 98.

\section{8}

WIEDEMANN,Thomas.GreekandRomanSlavery. Londres: Croom Helm Ltd, 1981, pp. 108-109. Ver também ALENCASTRO, Luiz Felipe de. O trato dos viventes. Op. Cit. p. 150. Na América do Norte, senhores de escravos também estavam atentos para escravos já ladinos, beligerantes. Ver WAX, Darold D. Preferences for Slaves in Colonial America. The Journal of Negro History, vol. 58, n 4 pp. 371-401, outubro de 1973. Ver especialmente, p. 373 e passim. Sobre o suicídio entre os escravos igbo, ver GOMEZ, Michael A. A quality of Anguish: The Igbo response to Enslavement in the Americas. In: LOVEJOY, Paul E.;TROTMAN, David V. (orgs.). Op. Cit., pp. 82-95. Segundo Gwendollyn Hall, apesar das opiniões negativas sobre os homens igbo, as mulheres dessanaçãoeramconsideradasemocionalmente mais estáveis do que os homens do mesmo grupo étnico, além de fisicamente atraentes e trabalhadorasdedicadas.HALL,GwendolynMidlo. Op. Cit., pp. 139, 140.

\section{9}

"Carta do Vice-rei do Brasil ao rei de Portugal", de 28 de julho de 1714, APEB, Seção Colonial e Provincial (CP), Ordens Régias, vol. 8, doc. 66; "Carta do governador do Rio de Janeiro", de 1726, AHU, códice 233, f. 19-19v; BOXER, Charles R. A idade de ouro do Brasil: dores de crescimento de uma sociedade colonial [1963]. Rio de Janeiro: Nova Fronteira, 2000, p. 70.

\section{0}

"Carta de José de Torres", de 1724, AHU, CU, São Tomé, cx. 4, doc. 118.

31

ELTIS,David;BEHRENDT,Stephen;RICHARDSON, David;FLORENTINO,Manolo.Voyages.Acessoem: 29 fev. 2016.

32

OLIVEIRA, Maria Inês Cortes de. Op. Cit., pp. 467, 50-53; VERGER, Pierre. Op. Cit., p. 79-82; SILVA JR., Carlos. Op. Cit., pp. 119-24.
O negócio de tabaco e ouro em pó da América portuguesa (este oriundo de contrabando) a troco de escravos no golfo do Benimestimulou o fluxo e refluxo de pessoas e mercadorias entre essas duas regiões atlânticas. Essa migração forçada resultou na concentração de certos grupos étnicosemalgumasáreas da América portuguesa, notadamentena Bahia, Rio de Janeiro e Minas Gerais. Contudo, além das dinâmicas econômicas do tráfico (troca de bens por cativos), essa concentração étnica decorre de outros aspectos.

Alguns grupos africanos eram preferidos a outros por suas supostas habilidades físicas e intelectuais. O comportamento e a reputação de certosgruposétnicosafricanoseraassuntodecorrespondênciasentreoBrasil e Amsterdã durante a dominação holandesa no nordeste açucareiro no século XVII. ${ }^{26} \mathrm{O}$ jesuíta André João Antonil (pseudônimo de João António Andreoni), porexemplo, afirmava no início do séculoXVIII que"[o]s Ardase Minassãorobustos", atribuindooutrasqualidadesaoscativosdediferentes regiões africanas. ${ }^{27}$ Esse afã classificatório, no entanto, não se resumia à Américaportuguesaenemmesmoàescravidãomoderna;háexemplosdas mesmas práticas na Roma antiga, em outras regiões das Américas durante a vigência do tráfico atlântico e em referência a outros grupos étnicos. ${ }^{28}$ No caso dos afro-ocidentais, malgrado a reputação rebelde dos minas, acentuada a partir da rebelião em Minas Gerais, em 1719, eles continuavam sendo os mais procurados para as minas por seus pretensos conhecimentos sobre mineração. Apelava-se atéà feitiçaria como explicação para a preferência pelos escravos dessa nação. ${ }^{29}$ Anos mais tarde, José deTorres, conhecido traficante na Costa da Mina, reforçou a preferência aos afro-ocidentais em detrimento dos africanos angolas. ${ }^{30}$

O volume do tráfico com a África Ocidental aumentou exponencialmente nas primeiras décadas do século XVIII. Entre 1700 e 1730 o golfo do Benim liderou a pauta de exportações de escravos no mundo atlântico. ${ }^{31}$ Comoresultado,umsignificantenúmerodeafro-ocidentais desembarcou naAméricaportuguesanesseperíodo.Entretanto,Angolacontinuavaadesempenharum papelessencial nosnegócios dotráfico,eapartirdadécada de 1730 retomou sua posição de liderança no comércio atlântico. Nesse sentido, a competição entre traficantes da carreira de Angola, há muito estabelecida, eaqueles da Costa da Mina - particularmente os comerciantes da praça da Bahia - gerou uma"propaganda"em torno de suas"peças". Ofoco dessa disputa eram os mineiros, que pagavam mais eem ouro pelas carregações de escravos. ${ }^{32}$

Entretanto,comojustificaromesmointeresseporpartedossenhores baianos? A imensa maioria dos minas, ardras e jejes na Bahia destinavam-se aos trabalhos nas plantations açucareiras no Recôncavo ou nas atividades deganho na cidade da Bahia (Salvador). Havia tambémaqueles enviados para as vilas de Jacobina e Rio de Contas, áreas mineradoras da capitania da Bahia. Em seu estudo sobre Rio de Contas, Katia Lorena Almeida identificou para o curto intervalo entre 1748-1749 que os afro-ocidentais eram $48,8 \%$ da população escrava (crioulos, pardos e indígenas inclusos); os centro ocidentais respondiam por $37,9 \%$ e os oriundos da contra costa africana eram apenas 1,5\%. Para um período mais amplo e comparando-se apenas os nascidos na África, 1724-1810, os africanos da 
ALMEIDA, Katia Lorena Novais. Escravos e libertos nas minas do Rio de Contas - Bahia, século XVIII. Tese (Doutorado em História Social). Faculdade de Filosofia e Ciências Humanas, Universidade Federal da Bahia, Bahia, 2012, pp. 79 (Tabela 5), 82 (Tabela 6).

\section{4}

"Parecer do Conselho Ultramarino sobre a representação de José dos Santos Torres", de 6 de março de 1732, AHU, Bahia, Avulsos, cx. 41, doc. 3709.

35

"Parecerdo Conselho Ultramarino ao vice-reido Estado do Brasil dá conta do deplorável estado que se acha reduzido o comércio da Costa da Mina", de 19 de janeiro de 1736, AHU, Bahia, Avulsos, cx. 54, doc. 4665.

36

"Parecer de Manoel Fernandes da Costa", de 17 de outubro de 1743, APEB, CP, Ordens Régias, vol. 41 , doc. $6 \mathrm{~B}$.

37

"Carta de Gaspar Pinheiro da Câmara Manoel para o Conselho Ultramarino", de 15 de outubro de 1766, AHU, CU, São Tomé, cx. 10, doc. 93.
Costa da Mina eram levemente superiores em número (48,3\%) quando comparados aos da África Centro Ocidental $(46,4 \%) .^{33}$

Gente experimentada no negócio de escravos atestava a predileção dos africanos da Costa da Mina já na década de 1730. José de Torres, homem de"inquietoespírito"mas profundoconhecedordaregião,afirmou por diversas vezes que somente os escravos da Costa da Mina serviam para as minas, ao contrário dos angolas, considerados "muito fracos". Naturalmente, a hipótese da questão física deve ser descartada, pois o que estava em jogo era o controle do envio de cativos para Minas Gerais, e não uma suposta falta de vigor físico dos centro ocidentais. Torres, no entanto, vai além, e lista algumas nações "próprias" para as minas, entre elas os ardras e"foois" (fons). ${ }^{34}$

Não se deve confiar totalmente em suas palavras, afinalTorres estava implicado em vários crimes contra o erário régio, além de ser interessado direto na continuidade do comércio com a Costa da Mina. José de Torres havia investido recurso próprio na ereção do forte de Ajudá, em 1721, e na época em que a correspondência foi escrita ainda lhe eram devidos "cinco contos e tantos mil réis" de despesas com a fortaleza, segundo alegava. Entretanto, seu depoimento sejunta aos que serão apresentados nos próximos parágrafos sobre a reputação dos afro-ocidentais no Brasil escravista do séculoXVIII. Na mesma época, comerciantes luso-brasileiros que negociavam em Apá reclamavam que os escravos lá adquiridos, além de mais caros por conta das taxas do rei de Apá, não pertenciam às nações costumeiras no tráfico. ${ }^{35}$

Havia, de fato, amplo interesse dos homens de negócio da Bahia no comércio de escravos com a África Ocidental, cujos cativos seriam destinados em grande parte para as minas. Durante as discussões sobre a reorganização do tráfico da Costa da Mina, em 1743, um desses negociantes, Manoel Fernandes da Costa, comerciante de grosso trato ativo há alguns anos, reclamava que "no tempo presente poucos escravos costumam vir da Costa da Mina daquelas nações, estimadas para as minas".36 Naquele momentonãohaviadisputasevidentescomtraficantes deoutrascarreiras. O comércio com a Costa da Mina já estava estabelecido e era hegemônico, emboratraficantesenvolvidoscomocomérciodeAngolacontinuassemem atividade na Bahia. Sua parecer visava apenas à Coroa portuguesa, razão pela qual seu depoimento merece alguma credibilidade.

Infelizmente Manoel não informou quais eram essas nações, mas suspeito tratar-se dos minas e jejes, ou dos gbè-falantes de forma geral. Mais de 20 anos depois, em 1766, certo Gaspar Pinheiro da Câmara Manoel, provavelmenteumcomercianteoufuncionáriorégio,escreveuao ConselhoUltramarino uma detalhada descrição dasilhas deSãoToméedo Príncipe, inclusive o comércio lá praticado. Em sua memória, ele informa que navios do Brasil paravam em São Tomé para abastecer-se ao troco de ouro em pó com os gêneros necessários para a travessia atlântica. Informa ainda que navios ingleses costumavam vender cativos às outras embarcações - inglesas ou de outras nações europeias - que aguardavam na ilha. O dado mais interessante, porém, refere-se ao comércio de escravos com a Américaportuguesa.SegundoCâmaraManoel,mandavam-senaviosàcosta do reino do Benim e ao litoral de Calabar, no golfo de Biafra, para o resgate deescravos,"queainda que sejam de menos reputação bastam para o serviço da terra, e se embarcam para o Brasil, e se vendem a menos preço que os da primeira reputação como Ardas, gejas [jejes], e ainda os Minas".37 
38

"Carta do diretor da fortaleza de Ajudá ao governador da Bahia", de 26 de junho de 1780, AHU, CU, São Tomé, cx. 18, doc. 20.

39

"Carta do governador de São Tomé ao governador daBahia", de8 denovembro de 1804, AHU, CU, São Tomé, cx. 37, doc. 29.

\section{0}

AKINJOGBIN, I. A. Dahomey and its Neighbours, 1708-1818.Londres:CambridgeUniversityPress, 1967, p. 146; LOVEJOY, Paul E. Transformations in Slavery. Op. Cit., pp. 80, 97-8. Ver também MORTON-WILLIAMS, Peter. The Oyo Yoruba and the Atlantic Trade, 1670-1830. In: INIKORI, J. E. (org.). Forced Migration: The Impact of the Export Slave Trade on African Societies. Londres: Hitchinson University Library, 1982, pp. 167-86. LAW, Robin. The Oyo Empire, c. 1600-c. 1836: A West African Imperialism in the Era of the Slave Trade. Oxford: Clarendon Press, 1977, pp. 225227.

41

LAW, Robin. Ouidah:The Social History of a West African Slaving 'Port', 1727-1892. Athens: Ohio University Press, 2004, p. 75.

42

ADAMS,John.RemarksontheCountryfromCape PalmastotheRiverCongo, IncludingObservations on the Manners and Customs of the Inhabitants, with Appendix Containing an Account of the European Trade with the West Coast of Africa (1823). repr., Londres: Frank Cass and Co., 1966, p. 220.

43

LAW, Robin. The Oyo Empire. Op. Cit., p. 226, 227.
A escrita do relato de Lisboa, por um súdito aparentemente não envolvido com o tráfico, torna suas observações dignas de crédito. É interessante a menção aos jejes, um denominação quase exclusiva da Bahia, o que sugere que o autor conhecia a escravidão baiana e/ou os grupos étnicos para látransportados. Deve-seainda salientarque, apesarda retração na produção aurífera desde meados do séculoXVIII, os afro-ocidentais continuavam em alta conta no mercado escravista, considerando a data da escrita do documento (1766). Entretanto, àquela altura a África Centro Ocidental já superara há muito a Costa da Mina nas exportações para o Brasil. Apesar de referir-se ao Brasil, é muito provável que o documento informasse sobre a reputação dos afro-ocidentais na Bahia onde, como sabemos, eram maioria.

O diretor da fortaleza de Ajudá explicou algo semelhante, ao afirmar que “[o]s cativos deste Ajudá [Uidá] tinham melhor valor em toda a parte do Brasil", e estes escravos, embora mais caros, tinham melhor reputação do que os de Porto Novo. ${ }^{38}$ No início do século XIX, o governador de São Tomé informava ao governador da Bahia que o tráfico em Uidá era mais proveitoso aos navios baianos do que em Porto Novo, pois naquele porto havia melhor saída para o tabaco baiano. E ainda concluía que os escravos vendidos via Uidá, ainda que mais caros, tinham melhor aceitação na Bahia. ${ }^{39}$

A preferência pelos escravos exportados de Uidá sobre Porto Novo parece guardar alguma relação com a origem dos africanos exportados nos dois portos. A partir da década de 1760, Porto Novo tornou-se um entreposto para os escravos exportados via Oyó, resultando numa maior diversidade étnica entre os cativos. Guerras e razias contra estados vizinhosrespondiam pelamaiorpartedosescravosobtidosporOyó.Asorigens desses cativos eram bastante variadas. Iorubás doleste, como osijexá, ekiti e yagba, foram vítimas dos ataques do exército de Oyó, mas a principal reserva de escravos provinha dos seus vizinhos do norte e do oeste (Bariba, Nupe e Haussá). Oyó recebia ainda tributos em escravos do Daomé, indicandoqueumanumerosaparceladecativosfalantesdegbèterminava sendo vendido ao tráfico atlântico via Porto Novo. ${ }^{40}$

A maioria dos escravos traficados através de Uidá, porto de escoamento dos escravos do Daomé, constituíam-se predominantemente por mahis (gbè-falantes) e secundariamente por anagôs (falantes de iorubá), resultante principalmentedasincursões daomeanas sobreesses grupos. ${ }^{41}$ Em Porto Novo, por outro lado, encontravam-se africanos de origens mais diversas, comomahis, iorubás, haussás, entreoutros, exportadosnasdécadas finais do século XVIII, reportou o negreiro inglês John Adams, bastante ativo na região no período. ${ }^{42}$ Mas Oyó não era a única fonte de cativos para Porto Novo; comerciantes do país Bariba e Nupe também traziam escravos paraaqueleporto,comoobservaramcomercianteseuropeusnadécadade $1780 .{ }^{43}$

Assim, presumoquea origem dosescravos nos dois portos responde aos interesses dos traficantes no tráfico envolvidos no comércio de escravos em Uidá em detrimento de Porto Novo. Havia uma relativa "homogeneidade étnica" entre os escravos comercializados em Uidá, o que não ocorria em Porto Novo. O tráfico atlântico não funcionava de maneira aleatória.Amaiorpartedosnaviosnegreirosadquiriamsuascargasemum, talvez dois, portos de embarque. O objetivo é simples: carregar o navio no menortempopossível,diminuiroscustosoperacionaisnosportosafricanos 
THORNTON, John K. Africa and the Africans. Op. Cit., p. 192-195. Ver também THORNTON, John K. A Cultural History of the Atlantic World, 12501820. Nova York: Cambridge University Press, 2012, pp. 333-341.

45

ELTIS, David; RICHARDSON, David. Atlas of the Transatlantic Slave Trade. Op. Cit., p. 88.

46

Ver LARA, Silvia Hunold. Fragmentos setecentistas: escravidão, cultura e poder na América portuguesa. São Paulo: Companhia da Letras, 2007, p. 160. LARA, Silvia Hunold. Linguagem,domíniosenhorialeidentidadeétnica nas Minas Gerais de meados do século XVIII. In: BASTOS, Cristiana Bastos; ALMEIDA, Miguel Vale de; FELDMAN-BIANCO, Bela (orgs.). Trânsitos Coloniais: diálogos críticos luso-brasileiros. Campinas: Editora da Unicamp, 2007, pp. 221-41.

47

"Patente do posto de Director geral da Costa da Mina, concedida a Felix Jozé de Gouvêa", de 06 de novembro de 1746, APEB, CP, Patentes e Alvarás (1745-1750), Maço 357, f. 40.

48

ELTIS,David;BEHRENDT,Stephen;RICHARDSON, David;FLORENTINO,Manolo.Voyages.Acessoem: 29 fev. 2016.

49

ELTIS, David; RICHARDSON, David. A New Assessment of the Transatlantic Slave Trade. In: (orgs.). Extending the Frontiers:

Essays on the New Transatlantic Slave Trade Database. New Haven e Londres: Yale University Press, 2008, p. 18.

50

ELTIS,David;BEHRENDT,Stephen;RICHARDSON, David;FLORENTINO,Manolo.Voyages.Acessoem: 29 fev. 2016.

51

VERGER, Pierre. Op. Cit., p. 79. e reduzir a mortalidade entre os cativos já embarcados. Ademais, escravos capturadosemguerrasmuitoprovavelmentepertenciamaoexércitodeum único Estado, pertencendo a um mesmo grupo étnico - ou pelo menos a povos uma mesma área linguístico-cultural.“Um navio inteiro poderia ser carregado não apenas com pessoas oriundas da mesma cultura, mas com pessoas que cresceram juntas", afirma John Thornton. ${ }^{44}$

A estrutura organizativa da empresa traficante incidia diretamente sobre os padrões de distribuição étnica dos africanos escravizados através domundoatlântico, atendendoainteresseseconômicoseredesdecomércio nas duas margens do Atlântico. ${ }^{45}$ No caso baiano, o interesse econômicos dos comerciantes sediados na Bahia no comércio com a Costa da Mina, através da venda detabaco de terceira (eeventualmente de primeira qualidade, oqueera proibido porlei) moldouos padrõesculturaiseétnicos daescravariabaiana no séculoXVIII.Aomesmotempo, aconsolidaçãodessepadrãoétnicoafro-ocidentalobservadonaBahiaestimulou entreostraficantes a busca por escravos da mesma região e da mesma nação, quando possível. Para esse fim, era necessário conhecimento dos grupos étnicos à disposiçãoparacompranacostaafricana,oupelomenosumanoção,ainda que rudimentar, de suas línguas. ${ }^{46}$ Por exemplo, um requisito importante para assumir o cargo do diretor do forte de Ajudá era a familiaridade coma língua local - muito provavelmente o fon, hueda e/ou hula. ${ }^{47}$

Os padrões de escolha dos cativos e dos portos de embarque fornecem evidência do grau de organização no processo de aquisição dos escravos destinados à Bahia. Dito de outra forma, ao contrário do que se possa imaginar os traficantes conheciam os grupos com os quais lidavame tinham suas escolhas. É muito provável que essas escolhas fossem motivadas pelos interesses do tráfico bem como pelas preferências dos senhores de escravos. E essa preferência bem podia ser moldada pelos padrões demográficos; afinal, cincodecadaoitoafricanos desembarcadosnaBahia no setecentos originavam-se da Costa da Mina. ${ }^{48}$ Certamente os comerciantes africanos estavam atentos a essa demanda.

Os portos da área GBÈ e o tráfico de escravos para a bahia setecentista

Angola liderou as exportações de escravos para a Bahia até o último quartel do século XVII. Segundo David Eltis e David Richardson, "[q]uase todos os escravos desembarcados na Bahia até 1678 vieram de Angola". ${ }^{49}$ Nãoéumexagero. Estimativas dessesmesmosautores dãocontaquenove de cada dez escravos que chegaram à Bahia entre 1649 e 1678 tiveram sua origem nos portos da África Centro Ocidental, principalmente Luanda. ${ }^{50}$ Mas uma crise de "bexigas", ou varíola em Angola, em 1684, criou as condiçõesparaqueosnegreirosbaianosprocurassemosportosdogolfodo Benim em busca de escravos, explica Verger. ${ }^{51}$ Essa afirmação, no entanto, precisa ser relativizada. Primeiro, os traficantes da Bahia conheciam e frequentavam a Costa da Mina desde o século XVI. Seu afastamento da região deveu-se a questões diplomáticas e da geopolítica do Atlântico Sul a partir de meados do século XVII, como veremos logo a seguir. Outrossim, não existe evidência robusta de que o surto de varíola tenha afastado os negreiros cariocas do mercado angolano de escravos. Ao contrário, a relação dos traficantes do Rio de Janeiro com a África Centro Ocidental se fortaleceu e consolidouaolongo do séculoXVIII. No caso dotráfico baiano, a partir de 1687 os alvarás de navegação apontam a Costa da Mina como 
52

VERGER, Pierre. Op. Cit. pp. 78-9. Sobre a atuação dos negociantes cariocas em Angola no século XVII, ver ALENCASTRO, Luiz Felipe. O trato dos viventes. Op. Cit. pp. 247-363. Sobre os séculos XVIII e XIX, ver FLORENTINO, Manolo. Em costas negras: uma história do tráfico deescravos entre a África e o Rio de Janeiro: séculos XVIII e XIX. São Paulo: Companhia das Letras, 1997; FERREIRA, Roquinaldo Amaral. Transforming Atlantic Slaving: Trade, Warfare and Territorial Control in Angola, 1650-1800. Tese (Doutorado em História). University of California at Los Angeles, 2003.

53

RODRIGUES, Raimundo Nina. Op. Cit., p. 35 (grifo meu); PARÉS, Luís Nicolau. A formação do Candomblé. Op. Cit. p. 24.

54

PARÉS, Luís Nicolau. A formação do Candomblé. Op. Cit., p. 43.

55

LAW, Robin. The Slave Coast. Op. Cit., pp. 118-19.

56

LAW, Robin. The Kingdom of Allada. Leiden: Research School CNWS, 1997, pp. 1, 85-105; LAW, Robin. The Slave Coast. Op. Cit., pp. 238-42, 245-47.

57

LAW, Robin. The Kingdom of Allada. Op. Cit., pp. 5-8.

\section{8}

Sobre Cartagena, ver SANDOVAL, Alonso de. Naturaleza Policia, Sagrada i Profana, Costumes i Ritos, Disciplina e Catechismo Evangélico de Todos Etiopes por el Padre Alonso de Sandoval. Sevilha: Francisco de Lira Impressor, 1627. Para uma edição crítica, ver SANDOVAL, Alonso de. Un tratado sobre la esclavitud (introdução, transcrição e tradução de Enriqueta Vila Vilar). Madri: Alianza Editorial, 1987. Para a Costa Rica, ver LOHSE, Russell. Africans into Creoles: Slavery, Ethnicity, and Identity in Colonial Costa Rica. Albuquerque: University of New Mexico Press, 2014, pp. 67-8. Uma lista de identificações étnicas do Peru na primeira metade do século XVIII confirma a predominância dos escravos "Aradas" ou "Araras", que perfaziam 157 dos 179 registros $(87,7 \%)$. Ver LAW, Robin. The Slave Coast. Op. Cit., p. 191.

\section{9}

LAW, Robin. Ouidah. Op. Cit., pp. 21-2; LAW, Robin. Ouidah as a Multi-Ethnic Community. In: CANIZARES-ESGUERRA, Jorge; CHILDS, Matt; SIDBURY, James (orgs.). The Black Urban Atlantic in the Age of the Slave Trade. Philadelphia: University of Pensilvania Press, 2013, p.46. Sobre a sujeição de Uidá a Alada, ver LAW, Robin. The Slave Coast. Op. Cit. p. 231.

60

LAW, ROBIN. The Slave Coast. Op. Cit., pp. 11820; LAW, Robin. Ouidah. Op. Cit., p. 30. região preferencial para a aquisição deescravos. ${ }^{52}$ Pode-se sugerir, portanto, a segunda metade da década de 1680 como o período em que a presença afro-ocidental na Bahia fez-se sentir demograficamente, em termos de volume do tráfico. Todavia, sua presença no Brasil remete, pelo menos, à década de 1640, quando"Minas, Ardas, Angolas e Crioulos"faziam parte do Regimento dos Homens Pretos de Henrique Dias, durante as guerras holandesas. ${ }^{53} \mathrm{~A}$ partir dessa e de outras evidências, Nicolau Parés sugere o período entre 1570 a 1647 como a data de introdução dos primeiros africanos da área gbè no Brasil.

Tem sido sugerido que o período entre 1570 e 1647 corresponde à introdução dos primeiros africanos da área gbè no Brasil. ${ }^{54}$ De fato, a regularidade dos contatos entre o golfo do Benim ea América portuguesa remonta a meados do século XVI. Naquela época, traficantes portugueses estabeleceram relações comerciais com os ijebus, através do canal de Lagos, etambém traficavamem PopoGrande(Hulagan). ${ }^{55}$ Ján no séculoXVII o reino de Alada, a principal entidade política da costa da África Ocidental antes da ascensão do Daomé, em 1724, consolidou-se como o principal fornecedor de escravos no golfo do Benim, através dos portos de Ofra principal porto de Alada até 1692, quando foi devastado pelo exército de Popo Pequeno - e Jakin (Djeken), em substituição a Ofra. ${ }^{56}$

Durante o século XVII, Alada foi frequentada por comerciantes portugueses-pioneirosnotráficonaregião-,holandeses (queestabeleceram uma feitoria em Ofra já em 1639, e outra em Apa em 1707), ingleses (a partir da década de 1650, embora uma feitoria em Ofra tenha sido erigida apenas em 1663 e mais tarde abandonada) e franceses (que também levantaram uma feitoria em Ofra)..$^{57}$ Os etnônimos "Arada", "Arara" (ou "Arará") encontrados na América espanhola, de Cartagena a Costa Rica - além de "Arda" ou "Ardra", na América portuguesa - refletem a participação de Alada no tráfico desse período. ${ }^{58}$

OsportuguesestambémimportavamescravosdeAlada, maisaleste, desdeo séculoXVI, mas suas relações intensificaram-seaolongo do século XVII. Os portugueses adquiriam "muitos escravos" em Alada para suas plantations em São Tomé e no Brasil no início do seiscentos, observou o escritor holandês De Marees. Ademais, há também evidência do estabelecimentodecomerciantesportuguesesemAlada.Documentoportuguêsde 1607 faz referência ao comércio de escravos em "Faloim", provavelmente uma menção aos hulas, grupo étnico a que pertencia parte da população de Uidá, àquela altura uma dependência de Alada. ${ }^{59}$ Este era, sem dúvida, o principal porto nogolfo doBenim, importandoanualmentecerca de 800 mil-réis em mercadorias, enquanto Popó importava metade desse valor, e Uidá apenas 200 mil-réis, segundo o mesmo documento. ${ }^{60}$

O domínio português na Costa da Mina foi desafiado a partir de fins do século XVI pelos Países Baixos. Desde sua fundação, em 1621, a West-Indische Compagnie (Companhia das Índias Ocidentais, WIC) promoveu uma política belicosa, infligindo várias baixas aos navios portugueses na ÁfricaOcidental.Ocorsoneerlandêsresultounaapreensãoe/oudestruição de várias embarcações portuguesas. Ainda no contexto da geopolítica do AtlânticoSul,osholandesesocuparamPernambuco,importantezonaaçucareira da América portuguesa, em 1630 e passaram a interessar-se pelo tráfico de escravos, resultando na tomada do Castelo de São Jorge da Mina (1637) e Luanda (1641). Mesmo após sua expulsão do Brasil, em 1654, os neerlandeses mantiveram-seativos na África Ocidental.Tendo sua basede 
Paraumavisãogeraldoconflitoluso-neerlandês, ver BOXER, Charles R. O império marítimo português, 1415-1825.SãoPaulo:Companhiadas Letras, 2002, pp. 120-40. Sobre as relações lusoholandesas na África Ocidental no seiscentos, ver VERGER, Pierre. Fluxo e Refluxo. Op. Cit., pp. 49-53; BOOGAART, Ernst van den; EMMER, Pieter $C$. The Dutch Participation in the Atlantic Slave Trade, 1596-1650. In: GEMERY, Henry A.; HOGENDORN, Jan S. (orgs.). The Uncommon Market: Essays in the Economic History of the Atlantic Slave Trade. Nova York: Academic Press, 1979, pp. 353-75; POSTMA, Johannes. The Dutch in the Atlantic Slave Trade, 1600-1815. Nova York: Cambridge University Press, 1990, p. 33; LAW, Robin. The Slave Coast. Op. Cit., pp. 12024; Sobre o domínio holandês no Brasil, ver os diversos trabalhos de MELLO, Evaldo Cabral de. Olinda restaurada. Guerra e açúcar no nordeste, 1630-1654. São Paulo: Editora 34, 2007; MELLO, EvaldoCabralde.Onegócio do Brasil:Portugal,os Países Baixos e o Nordeste, 1641-1669. São Paulo: Companhia das Letras, 2011.

62

BOOGAART, Ernst van den; EMMER, PieterC. The Dutch Participation in the Atlantic Slave Trade. Op. Cit., pp. 353-75; LAW, Robin. The Slave Coast. Op. Cit., p. 159; LAW, Robin. The Kingdom of Allada. Op. Cit., pp. 87-8.

63

BARLÉU, Gaspar. O Brasil holandês sob o Conde Maurício de Nassau: história dos feitos recentemente praticados durante oito anos no Brasil e noutras partes sob o governo do llustríssimo João Maurício Conde de Nassau etc., ora Governador de Wesel, Tenente-General de cavalaria das Províncias-Unidas Sobo Príncipe de Orange. Brasília: Senado Federal, 2005, p. 158.

\section{4}

GONSALVES de MELLO, José Antônio. Fontes para a História do Brasil Holandês (FHBH), vol. I. Recife: s.e., 1981, pp. 186-87 apud ALENCASTRO, Luiz Felipe. O trato dos viventes. Op. Cit., p. 150. Verainda LAW, Robin.The Kingdom of Allada.Op. Cit., p. 88.

65

ALENCASTRO, Luiz Felipe. O trato dos viventes. Op. Cit., p. 150. Maria Inês Oliveira já observara essa questão para o século XVIII baiano. Ver OLIVEIRA, Maria Inês Cortes de. Quem eram os "Negros da Guiné". Op. Cit. pp. 37-73.

66

"Acto da investigação testemunhal a que procedeu o Desembargador Antonio José da Fonseca Lemos, em cumprimento do quelhefará ordenado pela carta regia antecedente", de 20 de março de 1755, AHU, Bahia, Castro e Almeida (CA), doc. 1617.

\section{7}

"Parecer do Conselho Ultramarino sobre a carta de Gaspar de Brito Freire acerca dos efeitos do pau-brasil, falta de escravos, aumento e conservação do Brasil", de 14 de dezembro de 1644, AHU, Bahia, Avulsos, cx. 1, doc. 61. DocumentocitadoporLOPES,EdmundoCorreia.A escravatura(subsídios paraasuahistória).Lisboa: Agência Geral das Colónias, 1944, p. 115. operações na Costa do Ouro, os comerciantes batavos garantiam o suprimento de escravos para suas plantations no Caribe eauferiam os lucros do asiento com a América espanhola em 1667. Naturalmente, os holandeses também comerciavam com Alada, de onde retiravam "grandes lucros", informava um governador de SãoTomé. ${ }^{61}$ Entre 1636 e 1647 estima-se quea WIC adquiria cerca de 800 escravos anualmente; por volta de 1670, Alada exportava em torno de 3.000 africanos por ano, a maioria provavelmente adquirida pelos holandeses. ${ }^{62}$

Vale destacar que durante o domínio holandês em Pernambuco os africanosocidentaistinhampéssimareputação, particularmenteosardras, "muito preguiçosos, teimosos e estúpidos", segundo Gaspar Barléus..$^{63} \mathrm{Um}$ relatório do Brasil holandês à diretoria da WIC em Amsterdã recomendava a reavaliação do tráfico com a Costa da Mina, pois os africanos dessa região eram "obstinados, maus, preguiçosos e difíceis de adaptar-se ao trabalho".64 Entretanto, os mesmos afro-ocidentais eram os preferidos no Suriname e nos enclaves açucareiros antilhanos dos holandeses algumas décadas mais tarde, indicativo da estreita relação entre os interesses do tráfico e as preferências dos senhores nas Américas. ${ }^{65}$

Portugueses e outras potências europeias mantiveram seus negócios na região, embora aqueles fossem obrigados a pagar uma taxa de $10 \%$ sobre as mercadorias a bordo dos navios (conhecida como "daxa" ou "quartiamento") aos holandeses. ${ }^{66}$ Até a década de 1640 os portugueses ainda traficavam na Costa da Mina. Em 1644, o recém criado Conselho UItramarino recomendava que os mercadores fossem até"aos Rios de Guiné, arda [Alada], mina [provavelmente a Costa do Ouro, atual Gana], Lucumi [iorubá], Jaloyo [Jolof], mandinga, jabu [ijebu], Cacheu, a buscar negros que os levem a Bahia". ${ }^{67}$ Entende-se que o documento tenha deixado de ladoosafricanosangolas, poisàquelaaltura Luandaencontrava-sesobdomínio holandês. Ao mesmo tempo, o documentoé revelador dos locais de aquisição dos cativos que compunham a população africana na Bahia do séculoXVII.Contudo, um tratado de pazfirmado entre Portugal e os Países Baixos em 1641 reconhecia a soberania neerlandesa na Costa da Mina. Os portugueses retiraram-se do tráfico na região porcerca de 30 anos, até seu retorno, na década de 1680, em Uidá. 68

Nas décadas finais do século XVII os negreiros europeus mudaramo foco das operações para Uidá, porto vizinho de Ofra. Uidá era o porto marítimo sobcontroledoreinoHueda, quedesde 1703 eragovernado pelorei Huffon. Uidá apresentava condições excepcionais para os traficantes das potênciaseuropeias:volumeabundantedeescravosparacompranolitoral; menortempodeembarque, quandocomparadocomaCostadoOuro;menores preços em relação a outras regiões exportadoras (exceto o golfo de Biafra); tributos mais atrativos do que os praticados em Ofra. Além disso, a rebelião deOfra, em 1671, desempenhou um papelimportantena decisão dos traficantes europeus de transferir suas operações para Uidá. ${ }^{69}$ Àquela altura Uidá já buscava sua independência de Alada, embora continuassea reconhecer certa soberania deste. Durante o século XVIII Uidá e Alada tornaram rivais nos negócios do tráfico, embora Alada continuasse a fornecer o contingente de cativos vendido em Uidá até o início dos anos de $1720 .^{70}$ Uma "guerra comercial" entre os dois reinos se estabeleceu nas primeiras décadas do século XVIII. A fase crítica desse conflito encontra-se no intervalo entre 1705 e 1712; nesse período Alada tentou, por diversas vezes, bloquear o acesso de escravos para Uidá. ${ }^{11}$ Essa foi a tônica das relações 
68

LAW, Robin. The Slave Coast. Op. Cit., pp. 121-23. Algunsautoresargumentamqueos portugueses tiveram uma feitoria em Uidá na década de 1680. ESPARTEIRO, Ver António Marques. Portugal no Daomé (1471-1961). Lisboa: Agencia-Geral do Ultramar, 1961, p. 4; LAMPREIA, José D. EtnoHistória do Daomé. Subsídios para o seu estudo. Lisboa:Junta de Investigações do Ultramar, 1962, p. 281; TAVARES, António José Chrystêllo. Marcos fundamentaisdapresençaportuguesanoDaomé. Lisboa: Universitária Editora, 1999, pp. 26-31. Se esse foi o caso, deve ter sido uma construção efêmera, como afirma LAW, Robin. The Slave Coast. Op. Cit., pp. 134-35; LAW, Robin. Ouidah. Op. Cit., p. 34. Ver também RYDER, A. F. C. The Re-establishment of PortugueseFactories on the Costa da Mina to the Mid-Eighteenth Century. Journal of Historical Society of Nigeria, Vol. 1, No. 3, pp. 157-83, dezembro de 1958.

69

ELTIS, David. The Rise of African Slavery in the Americas.NovaYork:CambridgeUniversityPress, 2000, p. 182; LAW, Robin. Ouidah. Op. Cit., p. 46.

\section{0}

LAW, Robin. The Slave Coast. Op. Cit., p. 231; LAW, Robin. The Kingdom of Allada. Op. Cit., pp. 89-90.

71

LAW, Robin. The Slave Coast. Op. Cit., p. 252-254.

72 ELTIS, David. The Rise. Op. Cit., p. 182; LAW, Robin. Ouidah. Op. Cit. p. 30; MANNING, Patrick. Op. Cit., p. 120.

\section{3}

LAW, Robin. The Slave Coast. Op. Cit., pp. 12734; LAW, Robin. Ouidah. Op. Cit., pp. 31-3.

\section{4}

Sobre o ouro, consultar FERREIRA, Roquinaldo Amaral. A arte de Furtar: redes de comércio ilegal no mercado imperial ultramarino português (ca. 1690-c. 1750). In: FRAGOSO, João; GOUVÊA, Maria de Fátima Silva (orgs.). Na Trama das redes: Política e Negócios no Império Português, séculos XVI-XVIII. Rio de Janeiro: Civilização Brasileira, 2010, pp. 203-243. Sobre José de Torres, ver VERGER, Pierre. Fluxo e refluxo. Op. Cit., pp. 85-91; SILVA JR., Carlos. Op. Cit., pp. 32, 40, 55, 56, 179; FERREIRA, Roquinaldo. From Brazil to West Africa: Dutch-Portuguese Rivalry, Gold-Smuggling, and African Politics in the Bight of Benin (ca. 1700-1730). In: GROESEN, Michiel van (org.). The Legacy of Dutch Brazil. Nova York: Cambridge University Press, 2014, pp. 59-77. Para o interesse africano no ouro brasileiro, ver LAW, Robin. The Gold Trade of Whydah in the Seventeenth and Eighteenth Centuries. In: HENIGE, David; McCASKIE, T. C. (orgs.). West African Economic and Social History: Studies in Memory of Marion Johnson. Wisconsin: African Studies Program/University of WisconsinMadison, 1990, pp. 105-18.

\section{5}

VERGER, Pierre. O fumo da Bahia e o tráfico de escravos do golfo do Benim. Série Ensaios, №. 6. Salvador: Universidade Federal da Bahia, 1966; VERGER, Pierre. Fluxo e Refluxo. Op. entre os dois reinos por toda a década de 1710 .

Os números do tráfico tem algo a dizer sobre impacto do comércio europeu naquela zona. Uidá exportava anualmente cerca de 10.000 escravos na década de 1690; no auge das suas exportações (1700-1713), Uidá respondia por cerca de metade de todo o tráfico transatlântico, com aproximadamente 15.000 deportadosporano, númeroqueteriachegadoa 16.000-18.000 entre 1725 e 1726, e mesmo 20.000 em alguns anos. ${ }^{72}$

A crescente importância de Uidá no tráfico de escravos como local privilegiado do comércio de escravos reflete-se na construção de fortes europeus na região. ${ }^{73}$ No caso português, o interesse no tráfico em Uidá resultou na construção do forte São João Batista de Ajudá, obra do comercianteportuguês Josédos SantosTorresem 1721.Doisprodutosbrasileiros deram a vantagem aos comerciantes luso-brasileiros no golfo do Benim:o ouro e o fumo produzido na Bahia. ${ }^{74} \mathrm{Com}$ a crise da produção aurífera em Minas Gerais, em meados do setecentos, o tabaco converteu-se na principal moeda de troca por escravos ao longo do litoral ocidental africano. ${ }^{75}$

Nesseperíodo,ogolfodoBenimassistiuàascensãodoDaomé.Reino interiorano, o Daomé alimentava-se do banditismo e das razias aos reinos vizinhos. Graças a esses ataques, o Daomé fornecia parte significativa dos cativos exportados através de Alada e Uidá para as Américas. No final de 1715, já em aberta rebelião contra Alada, o Daomébuscou um acordocom o rei Huffon para negociar seus escravos diretamente para Uidá. ${ }^{76}$ Sob a liderança de Agaja (c. 1716-1740), porém, o Daomé decidiu assumir o protagonismo das transações comerciais com os europeus. Mas para esse fim era preciso eliminar os rivais. ${ }^{77}$

No alvorecer da década de 1720 Daomé avançou sobre os dois principais adversários políticos e comerciais no golfo do Benim. Primeiro conquistou Alada em 1724, aproveitando-se de uma disputa sucessória pelo trono. A derrota de Alada garantiu o acesso daomeano aos portos atlânticos através da vassalagem do dinâmico porto de Jakin. ${ }^{78}$ Três anos mais tarde, o exército daomeano avançou sobre Uidá, estabelecendo-o como seu principal porto de comércio. O governante de Jakin - que operava os negóciosdotráficodeformarelativamenteindependente,emborapagasse tributos ao Daomé - e o rei de Weme (este derrotado pelo Daomé em c. 1716), incitados pelodiretorholandês HendrikHertogh, organizaram uma coalizão anti-daomeana. Estes buscaram arregimentar o apoio de outros reinos atingidos em maior ou menor medida pela expansão do Daomé. A aliança, no entanto, malogrou. Jakin foi atacada em 1732 e completamente destruída em 1734. Com a conquista dos dois principais centros escravistas do litoral do golfo do Benim (Alada e Uidá) e a eliminação de portos rivais, o Daomé tornou-se o senhor do tráfico na região. ${ }^{79}$

Outros estados da região mostravam interesse em ampliar o comércio de escravos no litoral da Costa da Mina, a exemplo do reino iorubá de Oyó. Em resposta ao avanço daomeano, Oyó lançou uma série de ataques a partir da segunda metade da segunda metade da década de 1720 . Suas incursõesemterritório daomeanoduraramaté 1747 , quandofoicelebrado um acordo de paz mediante pagamento de tributos por Tegbesu, rei do Daomé (1740-1774). ${ }^{80}$

Entrementes, os conflitos tornaram as estradas inseguras para mercadores particulares, afetaram as expedições para captura de escravos, desarticularam as redes negreiras na região. Abriu-se a oportunidade para a ascensão de outros portos de comércio (os chamados "portos de 
Cit., pp. 37-47; NARDI, Jean Baptiste. O fumo brasileiro no período colonial: lavoura, comércio e administração. São Paulo: Brasiliense, 1996. LAW, Robin. The Slave Coast. Op. Cit., p. 136, argumenta que o tabaco e o ouro, dois produtos de grande demanda no golfo do Benim, foram responsáveis pela vantagem adquirida pelos portugueses no comércio da região e pela aquisição dos melhores escravos no litoral da Costa da Mina, conhecidos como "Portuguese slaves". Há evidência que os comerciantes europeus na Costa da Mina bem como os traficantes africanos aguardavam ansiosos pelas remessas de ouro brasileiro contrabandeado. Ademais, relativiza a importância do tabaco no comércio da região no século XVII, contrariando Pierre Verger. Para posição semelhante, ver KLEIN, Herbert S. The Atlantic Slave Trade (New Approaches to the Americas). 2a ${ }^{\text {a }}$ ed. Nova York: Cambridge University Press, 2010, p. 116.

75

LAW, Robin. The Slave Coast, Op. Cit., p. 257.

76

Ibidem, pp. 261-278.

\section{7}

Sobre Jakin no início da década de 1730, ver HARMS, Robert. The Diligent: A Voyage Through the Worlds of the Slave Trade. Nova York: Basic Books, 2002, pp. 227-264.

78

Sobre a ascensão do Daomé, ver AKINJOGBIN, I. A. Op. Cit., pp. 60-83; LAW, Robin. The Slave Coast. Op. Cit., pp. 278-308. Sobre a conquista de Uidá peloDaomé, ver LAW, Robin. Ouidah.Op. Cit., pp.50-2. Para uma narrativa contemporânea sobre o ataque, ver SNELGRAVE, William. A New Account of Guinea, and the Slave Trade [1734]. Londres: Frank Cass \& Co., 1971, pp. 13-5.

\section{9}

"Carta para o Director Francisco Pereira Mendes", de 15 de junho de 1728, APEB, CP, Alvarás, Livro 443, f. 79, 79v. LAW, Robin. The Oyo Empire. Op. Cit. A respeito de suas investidas sobre o Daomé, ver, principalmente, pp. 157-69.

\section{0}

Sobre os "portos de baixo", ver SILVA JR., Carlos da. The Ports of the Bight of Benin and the Legal Slave Trade to Bahia, 1750-1815. IN: Canadian Association of African Studies. Ottawa: Carleton University, maio de 2013.

\section{1}

Sobre os "portos de baixo", ver SILVA JR., Carlos da. The Ports of the Bight of Benin and the Legal Slave Trade to Bahia, 1750-1815. IN: Canadian Association of African Studies. Ottawa: Carleton University, maio de 2013.

82

Para alguns títulos, ver HOBSBAWM, Eric. A Era das Revoluções, 1789-1848. Rio de Janeiro: Paz e Terra, 2009 [1962]; JAMES, C. L. R. The Black Jacobins. Nova York: Vintage, 1963; GEGGUS, David (org.).The Impact of the Haitian Revolution in the Atlantic World. Columbia: University of South Carolina Press, 2001; FERRER, Ada. baixo", a leste de Uidá), como Ekpe, Apa e Badagri. No final da década de 1750, Porto Novo, reino formado por refugiados da família real de Alada, ascendeucomorivalcomercialdoDaomé,tornando-seoprincipal portode escoamento dos cativos de Oyó. ${ }^{81}$ As disputas entre os dois reinos duraram até o início do século XIX, quando as "revoluções" no mundo atlântico - a revolta de escravos em São Domingos, o jihād fulani de 1804 - e uma nova ordem política sob a liderança da Inglaterra, após a abolição do tráfico britânico, em 1807 - seguida da proibição do comércio de escravos ao norte do Equador, em 1815 - transformaram definitivamente os negócios do tráfico. ${ }^{82}$

Entreasprincipaistransformaçõesobservadasnesseperíodo,interessa-nos a deportação em massa de africanos iorubás, conhecidos na Bahia como nagôs. Estes foram escravizados durante as guerras intestinas que varreram o território iorubá entre as décadas de 1820 e 1830 que resultaram na exportação de milhares de pessoas para as Américas. A partir dosanos de 1820 os nagôs superaram demograficamente os gbè falantes, transformando o panorama étnico da Bahia oitocentista. ${ }^{83}$

As dinâmicas políticas entre os reinos escravistas explicam a variedadeétnicadapopulaçãodeportadapelogolfodoBenim.Bastamencionar brevemente que grande número de africanos terminaram escravizados durante algumas guerras movidas pelo Daomé. Foram de seis a oito mil cativos em Alada; em Uidá cativaram mais de 10 mil pessoas, e mais de quatro mil foram reduzidasáescravidãoem Jakin. ${ }^{84}$ Osfalantes das línguas gbè compunham a maior parte dos cativos destinados ao tráfico atlântico, embora falantes de iorubá e povos do Sudão Central, como os haussás e ostapas (povodeNupe)tambémcontribuíssemsignificativamentecomas exportações, sobretudonasúltimas décadas doséculoXVIII.Paraoquenos interessa nesse artigo, estima-se que a taxa de deportação de povos gbè tenha superado os $90 \%$ entre 1640 e o final da década de 1680 , período dominantedeAladanocomércionegreiro. ${ }^{85}$ Paraoperíodoimediatamente posterior (1690-1740), de hegemonia de Uidá no tráfico, estimativas dão conta de que 80 a $90 \%$ de todos os deportados do golfo do Benim eram gbè-falantes. ${ }^{86}$ Desconfia-se, noentanto, queessa porcentagemcontenha umasubrepresentaçãodos africanosiorubásentreosdeportados ${ }^{87} \mathrm{Háum}$ evidentecrescimentononúmerodeescravosiorubásnas Américasapartir da segunda metade do séculoXVIII. ${ }^{88}$ Os inventários post mortem baianos tendem a confirmar esse fenômeno. Estimativas mais recentes reduzem significativamente a proporção de falantes de gbè a partir de 1725 . Ainda assim, estes representavam pelo menos $50 \%$ dos deportados do golfo do Benim entre esta data e a ascensão de Lagos, no início do século XIX. ${ }^{89}$

Uma consequência trágica do volume do comércio de escravos para as Américas foi a perda anual de $3 \%$ da população gbè para o tráfico atlântico. A maior taxa de perda populacional ocorreu sob Agaja, quando essenúmerose aproximou dos $4 \%$ na década de 1710, permanecendoacima dos $3 \%$ no restante do seu reinado. ${ }^{90}$ Para a segunda metade do século XVIII há uma retração no peso dos cativos da área gbè (62\%) em favor dos iorubás e dos escravos do Sudão Central, nas últimas décadas do século XVIII, ambos exportados principalmente via Porto Novo e Badagri.. ${ }^{91}$

Esses cativos eram adquiridos entre povos vizinhos e em áreas densamente populosas, sobretudo nas regiões costeiras, em distâncias inferiores a 200 quilômetros do litoral, afirma Patrick Manning. Para esse autor, " $[\mathrm{n}] \mathrm{o}$ golfo do Benim, portanto, a noção acerca de povos costeiros 
Freedom's Mirror: Cuba and Haiti in the Age of Revolution. Nova York: Cambridge University Press, 2015; LAST, Murray. The Sokoto Caliphate. Nova York: Humanities Press, 1967; REIS, João José. Op. Cit., pp. 158-75; MELLO e SOUZA, Laura de; REIS, João José. Popular Movements in Colonial Brazil. In: CANNY, Nicholas; MORGAN, Philip. The Oxford Handbook of the Atlantic World, 1450-1850. Oxford e Nova York: Oxford University Press, 2011, pp. 563-64; LOVEJOY, Paul E. Jihad e escravidão: as origens dos escravos muçulmanos da Bahia. Topoi, Rio de Janeiro, v. 1, n. 1 (2000), p. 12; LOVEJOY, Paul E. Jihad na África Ocidental durante a "Era das Revoluções": em direção a um diálogo com Eric Hobsbawm e Eugene Genovese. Topoi, Rio de Janeiro, v. 15, n. 28, pp. 22-67. janeiro - junho de 2014.

83

LAW, Robin. The Oyo Empire. Op. Cit., pp. 245299; REIS, João José. Rebelião escrava no Brasil. Op. Cit., pp. 159-175.

\section{4}

Sobre Alada, ver "Bulfinch Lambe", de 27 de novembro de 1724, In: SMITH, William. A New Voyage to Guinea. Londres: Frank and Cass, 1967 [1744], 187; sobre Uidá, ver "Carta do vice-rei do Brasil ao rei de Portugal", de 18 de junho de 1727, APEB, CP, Ordens Régias, vol. 21, doc. 58. Sobre Jakin, ver SNELGRAVE. Op. Cit., p. 7; “Carta de Francisco Pereira Mendes, diretor do Forte de Ajudá, ao vice-rei do Estado do Brasil", de 14 de abril de 1724, APEB, CP, Ordens Régias, vol. 18, doc. 56.

\section{5}

MANNING, Patrick. Slavery, Colonialism and Economic Growth in Dahomey, 1640-1960. Cambridge:CambridgeUniversityPress, 1982,pp. 335-39, apêndice 2.

86

Ibidem.

87

LOVEJOY, Paul E. Transformations in Slavery. Op. Cit., p. 80.

88

LOVEJOY, Paul E. The Yoruba Factor in the TransAtlantic Slave Trade. In: FALOLA, Toyin; CHILDS, Matt. The Yoruba Diaspora in the Atlantic World. Bloomington e Indianápolis: Indiana University Press, 2004, p. 43, 44.

\section{9}

ELTIS, David. The Diaspora of Yoruba Speakers, 1650-1865. In: FALOLA, Toyin; CHILDS, Matt. The Yoruba Diaspora in the Atlantic World. Op. Cit., p. 27.

\section{0}

MANNING, Patrick. Slavery. Op. Cit., pp. 10, $32-3,40$.

\section{1}

Ibidem, pp. 335-39, apêndice 2. Ver, MANNING, Patrick. The Slave Trade in the Bight of Benin, 1640-1890". In: GEMERY, Henry A.; HOGENDORN, Jan S. (orgs.). The Uncommon Market: Essays in the Economic History of the Atlantic Slave Trade. Nova York: Academic Press, 1979, pp. 125-29. vendendo escravos obtidos no interior distante é exagerada".92 Paul Lovejoy vai um pouco além, estimando a distância da captura de escravos em 200-300 quilômetros da costa, considerando sobretudo o afluxo de gente doSudãoCentral observadonofinal doséculoXVIII. ${ }^{93}$ Seorigenslitorâneas para os escravos gbè falantes (hulas e huedas principalmente) podem ser observadas para os anos iniciais do século XVIII, com o passar das décadas a fronteira escravista moveu-se progressivamente para o interior, particularmente a partir dos anos de 1760-1770, alcançando povos iorubás e centro-sudaneses. Aoperações daomeanas decaptura deescravosem sua imediata vizinhança, ao norte de Abomé, assemelham-se ao modelo de extensão das fronteiras escravistas em direção ao interior, proposto por Paul Lovejoy, porém dentro dos limites sugeridos por Manning. ${ }^{94}$ As zonas escravistas na Costa da Mina guardam importantes diferenças com outras regiões africanas como Benguela, na África Centro Ocidental, onde a fronteira escravista moveu-se para o litoral. ${ }^{95}$ No caso do golfo do Benim, o deslocamento dos locais de captura em direção ao interior, observado acima, pode ter sido a solução para proibição da venda de pessoas dentro do reino do Daomé para o tráfico atlântico.

O que estes dados revelam sobre as origens dos cativos no tráfico atlântico? Ora, dois grupos foram particularmente predados pelo tráfico atlântico: os povos mahis, da fronteira norte do Daomé, "campo de caça a escravos", segundo Akinjogbin, e os anagôs, da região do Egbado, a nordeste. Estes, iorubás, preados pelo Daomée Oyó; aqueles, falantes de gbè, vítimas preferenciais das incursões daomeanas (guerras anuais, razias) ao longo do século XVIII. ${ }^{96}$

Entretanto, outros grupos foram reduzidos à escravidão e deportados para as Américas. Malgrado a grande concentração de escravos gbè deportados a partir do golfo do Benim, já observada no decorrer do seiscentos, guerras e razias atingiram outros povos ao longo dos séculos. $A$ lista de identificações étnicas do padre Labat ilumina a variedade étnica dos africanos deportados através do golfo do Benim nas primeiras décadas do século XVIII. Labat registrou escravos da área gbè (Aradas e Foins, i.e.,Fons), iorubás (Anagôs), Quiambasou Chambás (grupo donoroestedo Daomé, voltaicos) e mesmo gente da Costa do Ouro, como os Minas (que nessecontextodevesereferiraoshabitantes dePopoPequeno, refugiados da expansão Akwamu na década de 1680). ${ }^{97}$

Como já observamos no caso do tráfico luso-brasileiro, há evidência da preferência dos negreiros por cativos da área gbè, exportados via Daomé, até meados do século XVIII. Mesmo comerciantes de outras nações, como os franceses, asseveraram a preferência pelos escravos do Daomé. ${ }^{98}$ "Aradas"(Aladas) e minas comumente aparecem na documentação baiana sobreescravidão, os primeiros nas décadasiniciais do séculoXVIII,eosminas durante todo o setecentos, como um rótulo para africanos da Costa da Mina.

Em seu estudo sobre alforrias para a Bahia, Stuart B. Schwartz identificou 126 africanos da Costa da Mina ( 112 minas, 10 ardas e quatro jejes) entre 1684 e $1745 .{ }^{99}$ Este número representa $43 \%$ dos africanos alforriados noperíodo,segundosuaamostragem. Essesdadosreforçamapredominância do termo mina como denominação para os afro-ocidentais. Ademais, confirmam que o termo jeje tornou-se mais operacional a partir da segundametadedoséculoXVIII.Outros,comoosanagôs,surgemeventualmente duranteaprimeirametadedoséculo, mascrescememnúmeronodecorrer do setecentos. ${ }^{100}$ 
MANNING, Patrick. Slavery. Op. Cit., pp. 11, 29, 32; MANNING, Patrick. Slavery and African Life: Occidental, Oriental, and African Slave Trades. Nova York: Cambridge University Press, 1990, p. 68

93

LOVEJOY, Paul E. Transformations in Slavery. Op. Cit., p. 79. Naturalmente, essas distâncias variavam cronológica e regionalmente. NaÁfrica Centro Ocidental, por exemplo, as distâncias passaram de 300 quilômetros no século XVII para 600-700 quilômetros no oitocentos. Ver MANNING, Patrick. Slavery and African Life, Op. Cit., p. 70.

\section{4}

LOVEJOY, Paul E. Transformations in Slavery. Op. Cit., pp. 80, 85 .

\section{5}

LAW, Robin. The Slave Coast. Op. Cit., p. 190; MANNING, Patrick. Slave Trade in the Bight of Benin. Op. Cit., pp. 125-27.

\section{6}

LAW, Robin. The Slave Coast. Op. Cit., p. 190; MANNING, Patrick. Slave Trade in the Bight of Benin. Op. Cit., pp. 125-27.

97

MANNING, Patrick. Slave Trade in the Bight of Benin. Op. Cit., pp. 125-27. Para o perfil étnico dos escravos africanos em diferentes partes das Américas no século XVII, ver SANDOVAL, Alonso de. Naturaleza. Op. Cit.; SANDOVAL, Alonso de. Un tratado sobre la esclavitud. Op. Cit. Sobre o século XVIII, ver LABAT, Jean- Baptiste. Op. Cit., vol. ii, p. 125-130. Sobre esse tema, ver também AKINJOGBIN, I. A. Op. Cit., p. 134; LAW, Robin. The Slave Coast. Op. Cit., p. 188-90; PARÉS, Luís Nicolau. A formação do Candomblé. Op. Cit., p. 49. Consulte-se ainda LAW, Robin. Ouidah. Op. Cit., p. 75. A tradução"slave raiding ground"é de REIS, João José. Magia Jeje na Bahia: a invasão do Calundu do Pasto de Cachoeira, 1785. Revista Brasileira de História, vol. 8, n 16, pp. 57-81, mar-ago. 1988. Por fim, ver ELTIS, David. Africa, Slavery, and the Slave Trade, Mid-Seventeenth to Mid-Eighteenth Centuries. In: CANNY, Nicholas; MORGAN, Philip (orgs.). The Oxford Handbook of the Atlantic World. Op. Cit., pp. 271-286, para uma visão geral das origens dos escravos exportados pelo tráfico transatlântico.

\section{8}

"Carta do diretor do forte francês ao diretor da Companhia das Índias", de 31 de janeiro de 1744, Archive Nationale d'Outre Mer (ANOM), C6/25. Agradeço a Roquinaldo Ferreira por esse documento. AKINJOGBIN, I. A. Op. Cit., p. 134; MANNING, Patrick. Slave Trade in the Bight of Benin. Op. Cit., p. 127.

99

SCHWARTZ, Stuart B. Alforrias na Bahia, 1684-1745. In: _. Escravos, roceiros e rebeldes. Bauru,SP:EDUSC, 2001, p. 187.Schwartz identificou sub-gruposminas, como"Mina Ladini" (provavelmente ladino, i.e, escravo já conhecedor da língua e costumes locais), "Mina Courani" (courano, grupo bastante presente em Minas Gerais, com menções esparsas na Bahia e no Rio de Janeiro) e "Mina Sabara" (Savalu, região ao norte de Abomé, antiga capital do Daomé).
Apesar do foco desse artigo nessas três nações, outros falantes de gbè compunham a paisagem étnica afro-ocidental na Bahia setecentista. Cativos couranos, coda/codavis e savalus surgem em diferentes registros, sobretudo nos inventários post-mortem e nas cartas de alforria. ${ }^{101}$ Sua proporção, no entanto, é bastante inferior a dos outros grupos que temos discutido até agora. Há ainda os fons (grupo étnico dominante no antigo reino do Daomé), sobre quem existem apenas registros esparsos em diferentes regiões da América portuguesa: Salvador, no recôncavo e nas zonas mineradoras da Bahia, em Minas Gerais e no Rio de Janeiro. ${ }^{102}$ Mais raramente, recorreu-se ao designativo"Daomé",em clara menção ao reino deorigemdessesindivíduos;assimforadenominadooafricanorecém-chegado batizado como Jozé, oriundo da Costa da Mina denação"Dayomé".103 A escassez dos registros confirma que as severas restrições à venda de súditos do Daomé, fossem estes fons ou oriundos de grupos incorporados às suas fronteiras, continuava em vigor. ${ }^{104}$ Nesse caso, é provável que tais escravostenham sidoapanhadosnas guerrasqueassolaramogolfodoBenim no século XVIII. Alternativamente, terminaram nos porões dos navios europeus por condenações judiciais, venda em tempos de seca e/ou fome ou ainda como punição a adversários políticos. ${ }^{105}$

Os números do tráfico atlântico na área GBÉ e a demografia da escravidão Afro-ocidental na Bahia do século XVIII

A era dos "senhores da guerra" (warlords), observada durante o século XVIII na costa ocidental africana, refletiu no aumento exponencial do número de cativos destinados ao tráfico atlântico. ${ }^{106}$ No caso da Costa da Mina,asdinâmicaspolíticasobservadasnosparágrafosanterioresprovocaram conflitos que, por sua vez, geraram uma oferta elástica de prisioneiros de guerra. Concomitantemente, outros métodos de aquisição de cativos vigeram por todo o período do tráfico atlântico.

O golfo do Benim destacou-se na pauta de exportações de escravos, principalmente a partir do século XVIII. Dados do Transatlantic Slave Trade Database demonstram que o golfo do Benim contribuiu com aproximadamente 1,999 milhão do total de 12,5 milhões de africanos deportados para as Américas ao longo de mais de quatro séculos. Se considerarmos apenas o século XVIII, do golfo do Benim saíram mais de 1.284 .586 em direção à escravidão transatlântica. Essa cifra representa quase $20 \%$ dos africanos traficadosnaqueleséculo.ApenasasexportaçõesdaÁfricaCentroOcidental superaram os números da Costa da Mina. Foram mais de 2.365.000 escravos (36\%) transportados em negreiros para a outra margem do Atlântico - a maioria esmagadora para o Brasil. ${ }^{107} \mathrm{~A}$ tabela I apresenta os dados para o tráfico atlântico nas diferentes regiões africanas ao longo do setecentos. 
100

Para a presença anagô em Salvador na primeira metade do século XVIII, APEB, SJ, 04/1614/2083/08, Inventário post-mortem de Francisco Gonçalves Dantas (1738); “Carta do provedor da alfândega da Cidade da Bahia, Domingos da Costa de Almeida ao rei [D. João V] a informar da relação das embarcações que vieram da Costa da Mina", de 27 de julho de 1735, AHU, Bahia, Avulsos, cx. 52, doc. 4541. Sobre mais detalhes dessa viagem, ver ELTIS, David; BEHRENDT, Stephen; RICHARDSON, David; FLORENTINO, Manolo. Voyages, \# 50615. Acesso em: 12 jan. 2016 ; ver SILVA JR., Carlos da. Identidades Afro-Atlânticas. Op. Cit., pp. 212-14; SILVA JR., Carlos da. Tráfico, escravidão e comércio em Salvador do século XVIII: a vida de Francisco Gonçalves Dantas (1699-1738). In: REIS, João José; AZEVEDO, Elciene (orgs.). Escravidão e suas sombras. Salvador: Edufba, 2012, pp. 167-68.

101

"Alforria de Michaela nação courana", de 30 de novembro de 1759, APEB, SJ, Livro de Notas do Tabelião (LNT), v. 103, f. 107-107v; "Alforria de Catherina do gentio da Mina de nação Savaru (Savalu)", de 26 de março de 1761, APEB, SJ, LNT, v. 102, f. 278v; "Alforria de Josefa Codá da Cosa da Mina", de 01 de abril de 1785, APEB, SJ, LNT, v. 125 , f. $256-256 \mathrm{v}$

102

SILVAJR., Carlosda.IdentidadesAfro-Atlânticas. Op. Cit., pp. 210-212; PARÉS, Luís Nicolau. A formação do Candomblé. Op. Cit., p. 96, n. 12; REIS, João José. Magia jeje na Bahia. Op. Cit.; ALMEIDA, Katia Lorena Novais. Op. Cit., p. 82; MAIA, Moacir Rodrigo de Castro. Op. Cit., pp. 59 (tabela 4), 72; SOARES, Mariza de Carvalho. Op. Cit., p. 201

103

Arquivo da Cúria Metropolitana de Salvador (ACMS), LivrodeRegistro deBatismos(LRB)/Pilar, 1790-1801, f. 80v (20/07/1794). Mais sobre essa denominação em REIS, João José. Magia jeje na Bahia. Op. Cit.; SOARES, Mariza de Carvalho. Op. Cit., p. 201

104

LE HERISSÉ, Auguste. L'Ancien royaume du Dahomey, moeurs, religion, histoire. Paris: Émile Larose, Libraire-Éditeur, 1911, pp. 56, 245, 291; LAW, ROBIN. The Slave Coast. Op. Cit., p. 277-78.

105

BAY, Edna. Wives of the Leopard: Gender, Politics, and Culture in theKingdom ofDahomey. Charlottesville e Londres: University of Virginia Press, 1998, pp. 43, 178-182 (sobre a deportação de Na Agotime ou Agontime). Mais exemplos de deportados políticos em AKINJOGBIN, I. A. Op. Cit., pp. 116, 171, 178-79, 186. Sobre Na Agotime, ver HERSKOVITS, Melville. Dahomey, an Ancient West African Kingdom. Nova York: J. J. Augustin, Publisher, 1938, i, p. 14, ii, p. 64; VERGER, Pierre. Uma rainha africana mãe de santo em São Luís. Revista da USP, n. 6, pp. 151-58, agosto 1990; ARAÚJO, Ana Lucia. History, Memoryand Imagination:NaAgontime, a Dahomean Queen in Brazil. In: FALOLA, Toyin; FWATSHAK, Sati U. (orgs.). Beyond Tradition:
Tabela I. Região de Origem dos africanos destinados às Américas, 1701-1800

\begin{tabular}{|c|c|c|c|c|c|c|c|}
\hline $\begin{array}{c}\text { Sen- } \\
\text { egambia } \\
\text { and } \\
\text { off-shore } \\
\text { Atlantic }\end{array}$ & $\begin{array}{l}\text { Sierra } \\
\text { Leone }\end{array}$ & $\begin{array}{l}\text { Windward } \\
\text { Coast }\end{array}$ & $\begin{array}{l}\text { Gold } \\
\text { Coast }\end{array}$ & $\begin{array}{l}\text { Bight } \\
\text { of } \\
\text { Benin }\end{array}$ & $\begin{array}{c}\text { Bight of } \\
\text { Biafra }\end{array}$ & $\begin{array}{c}\text { West Cen- } \\
\text { tral Africa } \\
\text { and St. } \\
\text { Helena }\end{array}$ & $\begin{array}{c}\text { South- } \\
\text { east Africa } \\
\text { and Indian } \\
\text { ocean } \\
\text { islands }\end{array}$ \\
\hline
\end{tabular}

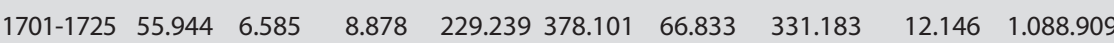

$\begin{array}{llllllllll}1726-1750 & 87.028 & 16.637 & 37.672 & 231.418 & 356.760 & 182.066 & 556.981 & 3.162 & 1.471 .724\end{array}$

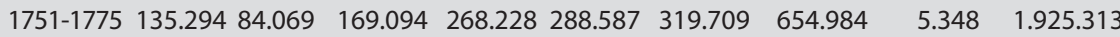

$\begin{array}{llllllllll}1776-1800 & 84.920 & 94.694 & 73.938 & 285.643 & 261.137 & 336.008 & 822.056 & 50.274 & 2.008 .670\end{array}$

Totals $\quad 363.186201 .985 \quad 289.582 \quad 1.014 .5281 .284 .585904 .616 \quad 2.365 .204 \quad 70.930 \quad 6.494 .616$

Fonte: ELTIS, David; BEHRENDT, Stephen; RICHARDSON, David; FLORENTINO, Manolo. Voyages: The TransatlanticSlaveTradeDatabase(Voyages),http://www.slavevoyages.org/tast/database/search.faces. Acesso em: 12 jan. 2016.

Quase 6,5 milhões de pessoas atravessaram o Atlântico no que foi considerado a "era de ouro" do tráfico de escravos. Há um boom nas exportações em diversas regiões africanas, como a Costa do Ouro, que deportou pouco mais de um milhão de pessoas; o golfo de Biafra (de onde se originaram os escravos de nação (alabar elbo nas Américas), que quase alcançou um milhão de indivíduos. Para o período 1700-1730, quase 500 milpessoas (480.836) foram deportadas dogolfodoBenim, a grandemaioria pelo porto de Uidá. No mesmo período, as exportações da África Centro Ocidental somaram 410.738 cativos. Dito de outro modo, três em cada 10 africanos que deixaram a África nas três primeiras décadas do século XVIII originaram-se do golfo do Benim. Houve uma retração do volume de exportação na segunda metade do século XVIII, com a ascensão da Costa do Ouro e do golfo de Biafra nos mercados atlânticos. Ainda assim, o envio de africanos às Américas nunca foi inferior a 10 mil escravos/ano, excetuando-se o decênio 1791-1800, quando estima-se que 9,3 mil escravos tenham sido embarcados. 
African Women and their Cultural Spaces. NJ: Africa World Press, 2011, pp. 45-65.

106

LOVEJOY, Paul E. Transformations in Slavery. Op. Cit., pp. 68.

107

ELTIS,David;BEHRENDT,Stephen;RICHARDSON, David;FLORENTINO,Manolo.Voyages.Disponível em:<http://www.slavevoyages.org/tast/database/ search.faces $>$. Acesso em: 01 de jan. 2016.

\section{8}

ELTIS,David;BEHRENDT,Stephen;RICHARDSON, David; FLORENTINO, Manolo. Voyages. <http:// www.slavevoyages.org/tast/database/search. faces.> Acesso em: 15 jan. 2016. Ver ainda SILVA, Daniel Barros Domingues da; ELTIS, David. The Slave Trade to Pernambuco, 1561-1851. In: ELTIS, David;RICHARDSON,David(orgs.). Extending the Frontiers. Op. Cit., p. 126, n. 37.

109

ELTIS,David;BEHRENDT,Stephen;RICHARDSON, David; FLORENTINO, Manolo. Voyages. <http:// www.slavevoyages.org/tast/database/search. faces.> Acesso em: 15 jan. 2016. Ver ainda SILVA, Daniel Barros Domingues da; ELTIS, David. The Slave Trade to Pernambuco, 1561-1851.In: ELTIS, David;RICHARDSON,David(orgs.). Extendingthe Frontiers. Op. Cit., p. 126, n. 37.
Tabela II. Exportações das carreiras nacionais, 1701-1800

\begin{tabular}{|c|c|c|c|c|c|c|c|c|c|}
\hline & $\begin{array}{c}\text { Senegambia } \\
\text { and off- } \\
\text { shore } \\
\text { Atlantic }\end{array}$ & $\begin{array}{l}\text { Sierra } \\
\text { Leone }\end{array}$ & $\begin{array}{c}\text { Windward } \\
\text { Coast }\end{array}$ & $\begin{array}{l}\text { Gold } \\
\text { Coast }\end{array}$ & $\begin{array}{c}\text { Bight of } \\
\text { Benin }\end{array}$ & $\begin{array}{c}\text { Bight of } \\
\text { Biafra }\end{array}$ & $\begin{array}{c}\text { West } \\
\text { Central } \\
\text { Africa } \\
\text { and St. } \\
\text { Helena }\end{array}$ & $\begin{array}{c}\text { South- } \\
\text { east } \\
\text { Africa and } \\
\text { Indian } \\
\text { ocean } \\
\text { islands }\end{array}$ & Totals \\
\hline $\begin{array}{l}\text { Spain / } \\
\text { Uruguay }\end{array}$ & 60 & 0 & 0 & 0 & 586 & 5,602 & 1,862 & 2,545 & 10,655 \\
\hline $\begin{array}{l}\text { Portugal/ } \\
\text { Brazil }\end{array}$ & 69,370 & 45 & 5,885 & 54,689 & 659,497 & 40,492 & $1,373,482$ & 29,544 & $2,213,004$ \\
\hline $\begin{array}{l}\text { Great } \\
\text { Britain }\end{array}$ & 181,360 & 138,582 & 183,474 & 595,560 & 238,511 & 785,704 & 409,366 & 12,739 & $2,545,296$ \\
\hline Netherlands & 778 & 829 & 78,030 & 84,144 & 50,158 & 1,498 & 114,577 & 0 & 330,014 \\
\hline U.S.A. & 27,575 & 31,395 & 6,814 & 108,970 & 1,604 & 3,766 & 5,980 & 3,200 & 189,304 \\
\hline France & 82,261 & 29,376 & 15,380 & 112,171 & 330,596 & 66,932 & 459,445 & 42,852 & $1,139,013$ \\
\hline $\begin{array}{l}\text { Denmark } \\
\text { / Baltic }\end{array}$ & 1,783 & 1,759 & 0 & 58,994 & 3,634 & 622 & 492 & 50 & 67,334 \\
\hline Totals & 363,187 & 201,986 & 289,583 & $1,014,528$ & $1,284,586$ & 904,616 & $2,365,204$ & 470,930 & $6,494,620$ \\
\hline
\end{tabular}

Fonte: ELTIS, David; BEHRENDT, Stephen; RICHARDSON, David; FLORENTINO, Manolo. Voyages:TheTransatlanticSlaveTradeDatabase(Voyages),http://www.slavevoyages.org/ tast/database/search.faces. Acesso em: 12 jan. 2016.

Em termos de participação das carreiras nacionais, os navios luso-brasileiros carregaram mais de $51 \%$ dos cativos do golfo do Benim nesse período.AFrança,fortecompetidora dosluso-brasileirosna ÁfricaOcidentalnasegundametadedosetecentos, exportoumenos dametade(25\%). A Inglaterra, principal nação traficante ao longo do século XVIII, mudou seu pólo de exportações para outras regiões. Grande concentração de navios ingleses pode ser observada no golfo de Biafra, onde os traficantes britânicos carregaram mais de 780 mil africanos; na Costa do Ouro (595 mil); e mesmoem Angola (409 mil). A participaçãodosnegreirosinglesesnogolfo do Benim caiu de $35 \%$ entre $1676-1700$ para $24 \%$ em $1701-1725$, com queda violenta entre 1726-1750 (apenas 7\%). ${ }^{109}$

Para o tráfico entre o golfo do Benim e a América portuguesa, sabe-se que a Bahia foi principal destino dos afro-ocidentais, embora outraszonas doBrasiltenham recebidodesembarques decativos da África Ocidental. A importância das conexões entre a Bahia e a Costa da Mina, há muitoenfatizadaspelahistoriografiabrasileira,ficamaindamaisevidentes com o exame da distribuição dos cativos segundo região, como mostra a tabela III. 


\begin{tabular}{llrr}
\hline & \multicolumn{2}{c}{ Bight of Benin } & \multicolumn{1}{c}{ Totals } \\
\hline Brazil & Amazonia & 2.464 & 2.464 \\
Bahia & 484.447 & 484.447 \\
& Pernambuco & 71.508 & 71.508 \\
& South-east Brazil & 30.722 & 30.722 \\
& Brazil unspecified & 4.591 & 4.591 \\
\hline Totals & 593.732 & 593.732 \\
\hline
\end{tabular}

Fonte: ELTIS, David; BEHRENDT, Stephen; RICHARDSON, David; FLORENTINO, Manolo. Voyages:TheTransatlanticSlaveTradeDatabase(Voyages), http://www.slavevoyages.org/ tast/database/search.faces. Acesso em: 12 jan. 2016.

110

ELTIS, David. Africa, Slavery, and the Slave Trade. Op. Cit., p. 284.

111

SILVA, Daniel Domingues da; ELTIS, David. Op. Cit., pp. 119 (tabela 3.9), 120.

112

STABEN, Ana Emília. Negócio dos escravos: o comércio de cativos entre a Costa da Mina e a Capitania de Pernambuco (1701-1759).

Dissertação(MestradoemHistória).Universidade Federal do Paraná, Paraná, 2008. Sobre o tabaco de Pernambuco, ver "Carta dos senhores de engenho de Pernambuco ao rei de Portugal", de 29deagostode1741,AHU,Pernambuco,Avulsos, cx. 57 , doc. 4899 .

113

Carta do governador geral do Brasil ao Secretário de Portugal, de 4 de março de 1703 APEB, CP, Ordens Régias, vol. 7, doc. 116. Ver também CAVALCANTE, Paulo. Negócios de Trapaça: caminhos e descaminhos na América Portuguesa (1700-1750). São Paulo: Hucitec/ FAPESP, 2006, p. 145. BOXER, Charles R. A idade de ouro do Brasil. Op. Cit., p. 70.

114

CartadogovernadorgeraldoBrasilaoSecretário de Portugal, de 4 de março de 1703, APEB, CP, Ordens Régias, vol. 7, doc. 116. Ver também CAVALCANTE, Paulo. Negócios de Trapaça: caminhosedescaminhosnaAméricaPortuguesa (1700-1750). São Paulo: Hucitec/FAPESP, 2006, p. 145. BOXER, Charles R. A idade de ouro do Brasil. Op. Cit., p. 70.

115

APEB, SJ, Inventários post mortem e testamentos, 1700-1750; SILVA JR., Carlos da. Identidades Afro-Atlânticas. Op. Cit., pp. 98-9.
O porto de Salvador recebeu mais de $80 \%$ de todos os escravos do golfo do Benim que chegaram ao Brasil ao longo do séculoXVIII.Em outras palavras, praticamente cinco em cada seis afro-ocidentais na América portuguesa terminaramajornada transatlântica na Bahia. Acredita-seque 2/3 de todos os africanos desembarcados na Bahia entre 1710 e 1770 tenham se originado do golfo do Benim. ${ }^{110}$ Entretanto, importa dizer que Salvador não foi o único porto negreiro do Brasil a comunicar-se com o golfo do Benim. Daniel Domingues e David Eltis estimam que sete de cada oito escravosdesembarcadosemPernambucoentre1720e1735originaram-se da Costa da Mina. ${ }^{111}$ Malgrado a reduzida aceitação do tabaco pernambucano no golfo do Benim, os traficantes desta capitania mantinham interesse no comércio com a região. Na década de 1740 eles organizaram uma esquadra anual com seis navios para navegar para a Costa da Mina. Essa decisão gerou uma forte reação e feroz oposição dos homens de negócio daBahia, defensores denúmeromenordeembarcações paraostraficantes do Recife. ${ }^{112}$

No caso dos comerciantes sediados na praça do Rio de Janeiro, havia um comércio ilícito com a Costa da Mina a troco de ouro em pó desde os primeiros anos do século XVIII. Por isso, proibiu-se em 1703 o envio de embarcações das "capitanias do Sul" à Costa da Mina. ${ }^{113}$ Malgrado a proibição, comerciantes do Rio continuavam a procurar a Costa da Mina com regularidade até a década de 1735, e navios da Bahia também supriam aquela capitania com africanos ocidentais. ${ }^{114}$ Como esse domínio demográfico reflete-se na demografia da escravidão africana em Salvador? Ora, segundoosinventários postmortem, minas,jejes, ardraseoutraspequenas naçõesafro-ocidentais respondiampornadamenosquequase $2 / 3(61,5 \%)$ dos africanos escravizados em Salvador entre 1700 e 1750. Uma análise individual por nação revela que os chamados minas - um rótulo para os africanos importados da Costa da Mina - constituíam 27,3\% de todos os africanos encontrados nessa documentação, enquanto ardras e jejes correspondem a 5,6\% e 4,6\%, respectivamente. Juntos, esses três grupos somam $37,5 \%$ dos registros dos africanos escravizados. Se incluirmos os chamados"gentios daCosta",termoaindamaisgenérico queodesignativo mina, mas que também designava, em sua maioria, gente deportada da Costa da Mina, esse número avança para 44,9\%. ${ }^{115}$ Entre os africanos ocidentais, aquelesprovenientesdaárealinguísticagbèerammaioriaabsoluta, com 299 registros, ou 75,3\%. 
116

APEB,SJ,Inventáriospostmortemetestamentos, 1750-17800. Agradeço a Luís Nicolau Parés por compartilhar cópia desse banco de dados.

117

APEB,SJ,Inventáriospostmortemetestamentos, 1700-1750. Para outros exemplos, ver SOARES, Carlos Eugênio Líbano; SILVA JR., Carlos da.'Uma nova guiné': africanos em inventários e registros de batismo na cidade da Bahia da primeira metade do século XVIII. História Unisinos 14 (3), pp. 243-257, set./dez. 2010.

118

PARÉS, Luís Nicolau. A formação do Candomblé. Op. Cit., p. 68.

119

Arquivo da Cúria Metropolitana de Salvador (ACMS), Livro de Registro de Batismos (LRB)/ Conceição da Praia, 1700-1751.

120

ACMS, LRB/Santo Antônio Além do Carmo, 1713-1734.

121

ACMS, LRB/Nossa Senhora do Óde Paripe, 16741721.
Para a segunda metade do século há situação semelhante. Os falantes de gbè (mina, jeje e alada) representam $15,7 \%$ do total de africanos escravizados (1330) registrados nos inventários. Ao incluirmos a denominação gentio da Costa esse percentual aumenta para 59,6\%. Em outro cenário, subtrairemos a genérica denominação gentio da Costa, para fins estatísticos. Nesse caso os africanos da área gbè ainda contribuem com $28,1 \%$ dos registros. Em todos os cenários apresentados os africanos da área gbètiveram forte participação no conjunto da escravidão africana em Salvador. ${ }^{116}$

É digno de nota que enquanto alguns termos se popularizavam, comonocaso dosjejes, outros praticamentecaíamem desuso,comoardra. Muito comum na primeira década do século XVIII (21 registros), a designação ardra passou a apenas 7 menções na década de 1740. Ena segunda metade do setecentos foram encontrados tão somente dois registros. A presença dos minas, por outro lado, passaram de meros sete africanos entre 1700-1710 para 88 ocorrências no intervalo 1741-1750. Do mesmo modo, os jejes não são nem mesmo mencionados até a década de 1730, quandosurgem trêsafricanos comessadenominação;na décadaseguinte eram27.Essesdadossãoimportantesporquedemonstramqueenquantoa concentração ardra ocorre entre $1700-1710$ (55,3\% dos casos). Nesse período Jakin ainda tinha expressiva participação na exportação deescravos eUidá deportava cativosfornecidos por Alada. Agrandemigração mina, se podemoschamá-ladessemodo, ocorreapartirda década de 1710.Nocaso dos jejes, por outro lado, sua concentração (90\%) encontra-se na década de1740,indicandoportantodeportaçãoanterior, provavelmentenadécada de $1730 .{ }^{117}$ No Recôncavo, o pico da presençajeje encontra-se no intervalo entre 1750 e 1780 . Nesse período os jejes constituíam quase $30 \%$ da população africana na área fumageira e $40 \%$ na área açucareira. Do ponto de vistadotráficoatlântico,esses dadosrevelamimportantestendências.Para o interesse desse artigo, nota-se direta correspondência entre o auge da exportação jeje e os reinos de Agaja, Tegbesu e os anos iniciais de Kpengla (1774-1789). ${ }^{118}$

Aanálisedosregistros debatismotambém revelamaspectosinteressantes da diáspora gbè na Bahia setecentista e suas lógicas de nomeação. $\mathrm{Na}$ Conceição da Praia, freguesia litorânea, coração econômico da Cidade da Bahia elocal de desembarque recém chegados da África, os minas eram $96,8 \%$ dos africanos batizandos, os ardras apenas $0,2 \%$, enquanto os jejes menos ainda, $0,05 \%$, para o período $1700-1751 .{ }^{119}$ No Santo Antônio Além do Carmo, freguesia semi-rural com alto índice de africanos entre seus moradores, os minas eram $89 \%$ dos africanos, os ardras apareciam com $4,1 \%$ dos assentos e nenhum jeje foi registrado. ${ }^{120}$ Dentre os 87 africanos encontrados na freguesia rural de Paripe entre 1674 e 1721, os minas representavam $75,9 \%$,enquantoosardraseram $17,3 \%$.Novamente,nenhum jejefoi identificado. ${ }^{21}$ Há, portanto, certa correlação entre os dados observadosnosinventários postmortem da primeira metadedoséculoXVIIIeos batismos do mesmo período. A exceção é a freguesia da Sé.

Na Sé, sede política e administrativa da cidade, há um repentino e impressionante aumento do número de jejes entre 1734-1742, que representavam cerca de $55 \%$ dos africanos, contra $35,5 \%$ dos minas e $0,2 \%$ dos ardras. A Sé, no entanto, trata-se de um caso particular. Não encontrou-se tal percentual de africanos jejes em nenhuma outra freguesia pesquisada. Eles surgem aos poucos na documentaçãoentre 1734e 1735, dominam os 
122

ACMS, LRB/Sé, 1734-1742; SILVA JR., Carlos da. Identidades Afro-Atlânticas. Op. Cit., pp. 164-66.

123

FARIA, Sheila de Castro. Sinhás Pretas, Damas Mercadoras: As pretas minas nas cidades do Rio de Janeiro e de São João Del Rey (1700-1850). Tese (Titular em História). Universidade Federal Fluminense, 2004, pp. 70-1. A autora ressalta, no entanto, asindicações no registros provinham do pároco bem como da comunidade.

124

Verumexemploem HARMS, Robert.Op.Cit.,p.202.

125

SOARES, Carlos Eugênio Líbano."Instruído na fé, batizado em pé": batismo de africanos na Sé da Bahia na primeira metade do século XVIII, 17341742. Afro-Ásia, 39 (2010), p. 99.

126

ACMS, LRB/Conceição da Praia, 1700-1751, f. 135.

127

PARÉS, Luís Nicolau. A formação do Candomblé. Op. Cit., pp. 81, 92-3.

128

SOARES, Carlos Eugênio Líbano."Instruído na fé, batizado em pé", p. 106.

129

APEB, SJ, 04/1571/2040/05, Inventário postmortem de João Lopes Fiúza (1741).

130

APEB, SJ, 03/1187/1656/08, Inventário post mortem de Roza Maria do Sacramento (1743).

131

APEB, SJ, 04/1776/2045/04, Inventário post mortem e Testamento de João Domingues Nogueira (1743)

132

APEB, SJ, 04/1620/2089/05, Inventário post mortem de Felício de Castro (1735). Há também exemplos deambivalência determos do golfo de Biafra bem como da África Centro Ocidental. Ver SILVA JR., Carlos da. Identidades Afro-Atlânticas. Op. Cit., pp. 102-03; PARÉS, Luís Nicolau. A formação do Candomblé. Op. Cit., 80-1. registros entre 1736 e 1740 e praticamente desaparecem em 1742. Uma possível hipótese, ainda a ser verificada, é o papel de escrivães e párocos mais cuidadosos e diligentes na coleta de informações e identificações de sinais, como as escarificações, as famosas "marcas étnicas" encontradas em alguns grupos africanos. Tais sinais, se corretamente interpretados, poderiam definir com alguma precisão a pertença étnica dos africanos. ${ }^{122}$ Sheila Farias explica que mesmo alheio à vida de todos os fregueses inclusive recém chegados africanos -, cabia aos párocos designar"o preto angola, mina, guiné, etc., ou o pardo escravo, forro, livre, etc.". 123

Carlos Eugênio Líbano Soares sugere que as oscilações nas proporções das nações africanas do período respondem aos fluxos de tráfico na Costa da Mina. De fato, na segunda metade da década de 1730 os negreiros europeus procuraram outros portos de comércio na Costa da Mina. A insegurança grassava em Uidá pelas constantes razias dos huedas e de PopoGrande. ${ }^{124}$ Osescravos também tornavam-secadavezmaisescassos. Nessaconjuntura,Apa,EkpeeBadagritornaram-seos portos preferenciais paraocomérciodeescravos. Asmudançasdeportos, portanto, responderia tambémpela mudançadosnomes denação.Aindasegundooautor, sendo a identidade jeje "criação exclusiva da Bahia", ele afirma "com segurança" que a Sé era o"locus de construção dessa identidade, não só na Bahia, mas noBrasil".125 Restasaberporqueessaetnogênesenãoocorreu, porexemplo, na freguesia da Conceição da Praia, a poucos quilômetros dali, onde apenas um jeje foi identificado em meio a 2103 registros: a africana Marcelina, batizadaem 27 desetembrode $1750 .{ }^{126}$ Seguindoseuraciocínio, poderíamos afirmar que a Conceição da Praia foi o "locus" da identidade mina na Bahia.

Ora,nessepontodeve-selembrarqueostermosminaejejepoderiam ser intercambiáveis. Se para a comunidade africana outros referenciais étnicoscontinuavamaoperar, para senhores deescravoseautoridadescoIoniais não havia prejuízo em denominar africanos da Costa da Mina como minas, jejes, ou mesmo ardras. ${ }^{127}$ Aliás, como aponta o próprio Soares, o párocoouescrivãodaSépodeterdesignadocomojejeumafricanoqueem outra freguesia seria conhecido como mina. ${ }^{128}$

Alguns casos ilustram as possibilidades de intercâmbio entre os termos que designavam a população gbè na Bahia. $\mathrm{O}$ africano Bento, por exemplo, foi designado como "arda e jeje" no inventário do poderoso senhordeengenhoJoãoLopesFiúza,em 1741. ${ }^{129}$ Essecasoéparticularmente interessante por duas razões. Primeiro, porque um termo do século XVII, já em desuso àquela altura (arda) convivia e, de fato se confundia com outro surgido poucas décadas antes no contexto da diáspora (jeje). Ademais, a expressão "arda ou jeje", como consta no documento, sugere que mais importante do que a nação era a possibilidade de definir a região de procedência desse cativos (a Costa da Mina). Jeje podia ainda ser confundidocommina, emborafossem de diferentesnações. Aganhadora Joanna foi chamada de mina na avaliação, e mais tarde designada como"Joanna gege" na partilha dos bens de Roza Maria do Sacramento, em 1743. ${ }^{130}$ Outroscasos:Antônio, denominadocodavi(grupoétnicodaareagbèainda nãoidentificado)notestamentodeJoãoDomingues Nogueira, foidescrito como "gentio da Costa da Mina" durante sua avaliação no inventário. ${ }^{131} \mathrm{E}$ Francisca, de nação courana, também foi chamada de mina no inventário de Felício Rodrigues. ${ }^{132}$

Uma disputajudicial entre o marido o pai pelos bens da falecida Caetana de Freytas, em 1750, demonstra mais uma veza ambivalência desses 
133

APEB, SJ, 03/1264/1733/19, Inventário postmortemdeCaetanadeFreitas(1750).Documento citado, embora não explorado, por PARÉS, Luís Nicolau.AformaçãodoCandomblé.Op.Cit.,p.81.

134

EIS, João José. Magia Jeje na Bahia. Op. Cit. O documento que trata da devassa foi novamente catalogado como APEB, SJ, Autos Cíveis, Devassa, 6A/182/11 ("Negros da nação Gêge"), mas encontra-se fora de uso. Outros exemplos desse intercâmbio de designações em Silva Jr., "Identidades afro-Atlânticas", pp. 112-115. PARÉS, Luís Nicolau. A formação do Candomblé. Op. Cit., 81. Para o Rio de Janeiro, SOARES, Mariza de Carvalho. Op. Cit., 199-230.

135

OLIVEIRA, Maria Inês Côrtes de. Viver e morrer no meio dos seus: nações e comunidades africanas na Bahia do século XIX. Revista USP, $n^{\circ}$ 28, dez-fev. 1995-1996, pp. 187-88.

136

SCHWARTZ,StuartB.SegredosInternos:escravos e engenhos na sociedade colonial (1550 - 1835). São Paulo: Companhia das Letras, 1988, p. 283. termos. Seu pai, Gabriel de Freytas Ribeiro, afirmava que o genro estava de posse de uma escrava por nome Jozepha, de naçãojeje. O marido, António Lamberto, reconhecia a posse de uma africana por nome Jozepha, mas de nação codavi. Em nova petição, o pai descreveu confusamente a africana como"jeje ou codavi". Já cinco testemunhas convocadas a depor não tiveram dúvidas eatestaram"codavi"como a nação da africana.Curiosamente, quando chamada a depor, a já liberta Jozepha definiu-se apenas como "preta forra".Talvez ela não se sentisse contemplada com as identificações atribuídas. Ou, quem sabe, buscasse a que lhe parecia mais operacional naquela situação, distanciando-a do universo da escravidão, embora a discriminação estivesse vinculada à cor da pele, fato ainda recorrente nos nossos dias. ${ }^{133}$

Não nos esqueçamos ainda da invasão ao calundu do pasto de Cachoeira, no Recôncavoem 1785.Todos os implicados na devassa, exceto um africano tapa (Nupe, do Sudão Central), pertenciam a área linguística gbè e foram descritos como jejes. Durante os autos, descobriu-se que eram mahi, dagomé(fon)ejejes. ${ }^{134}$ Comoexplicarasambivalênciasidentitáriasemtodos os casos acima senão pela similaridade linguístico-cultural entre as nações?

Conclusão

Havia na Bahia e em Minas Gerais, portanto, uma óbvia preferência por escravos falantes de gbè. Não por alguma suposta habilidade manual ou conhecimentomágico, comoimaginou ogovernadordoRiodeJaneiro, mas pela possibilidade de interação entre os cativos. Maria Inês Oliveira demonstrouque, no séculoXIX, quelibertos africanos costumavamadquirir escravos pertencentes à mesma nação (i.e., nagôs compravam nagôs). Isso ocorria, ela justifica, para otimizar a introdução do recém chegado no regime escravista na América, podendo obter, quase que imediatamente, os rendimentos da exploração daforça de trabalho escravo. ${ }^{135}$ Sugiroqueo mesmo ocorria com os donos de escravos na América portuguesa.

Obviamente, a oferta de cativos nos mercados de escravos dos dois lados do Atlântico desempenhava um papel crucial nesse processo de escolha. Stuart Schwartz, por exemplo, sugere que ainda que os senhores tivessempredileçõesporafricanos decertosgrupos, quevariavamsegundo a "moda e a disponibilidade", no fim e ao cabo comprava-se o que havia disponível. ${ }^{136}$ Tal argumento, no entanto, parece mais válido para o século XIX, quando as pressões internacionais pelo fim do tráfico de escravos no Brasil e os cruzadores ingleses na margem africana do Atlântico dificultavamaescolhadecativos.Importavacarregaromáximodepessoas (mulheres e crianças, inclusive, estes últimos introduzidos mais tarde no tráfico) nomenortempopossível.ParaoséculoXVIII,oscomerciantesadquiriamos escravosemcertasregiõeseostraficantesluso-brasileirosesforçavam-sea adquiri-los, atendendo a demanda brasileira, exceto em tempos de desorganização do comércio africano por guerras.

A questão das comunidades étnicas na diáspora nas diferentes regiões tem impacto crucial nas preferências dos senhores escravistas na América portuguesa.Proponhoolharcommaisatençãoparaesseaspecto: manterescravariasetnicamentehomogêneas, malgradooaparenteperigo, poderia resultar em lucros para seus proprietários. 
Bibliografia:

Fontes Manuscritas:

Archive nationale d'outre mer (ANOM)

c6/25.

Arquivo da cúria metropolitana de Salvador

Livro de Registro de Batismos/Sé, 1734-1742.

Livro de Registro de Batismos/Conceição da Praia, 1700-1751

Livro de Registro de Batismos/Santo Antônio Além do Carmo, 1713-1734

Livro de Registro de Batismos/Paripe, 1674-1721

Livro de Registro de Batismos/Pilar,1790-1801

Arquivo histórico ultramarino (AHU), conselho ultramarino (CU)

São Tomé, cx. 4, doc. 118; cx. 8, doc. 100; cx. 10, doc. 93; cx. 18, doc. 20; cx. 37, doc. 29.

Bahia, Avulsos, cx. 1, doc. 61; cx. 41, doc. 3709; cx. 52, doc. 4541; cx. 54, doc. 4665;

Pernambuco, Avulsos, cx. 57, doc. 4899.

Bahia, Castro e Almeida, doc. 1617;

Arquivo público do Estado da Bahia (APEB), Seção Judiciário (SJ)

Autos Cíveis, Devassa, 6A/182/11.

Inventários post mortem e testamentos, 1700-1800.

Livro de Notas do Tabelião (LNT), vol. 102; vol. 103; vol. 125.

Arquivo público doEstado da Bahia (APEB), seçãocoloniale provincial(CP) Ordens Régias, vol. 7, doc. 116; vol. 8, doc. 66; vol. 18, doc. 56; vol. 21, doc. 58; vol. 41, doc. 6B;

Patentes e Alvarás (1745-1750), Maço 357.

Páginas eletrônicas:

ELTIS, David; BEHRENDT, Stephen; RICHARDSON, David; FLORENTINO, Manolo.Voyages:TheTransatlantic SlaveTrade Database (Voyages). Disponívelem:<http://www.slavevoyages.org/tast/database/search. faces. $>$.

PARÉS, Luís Nicolau (org.). Práticas religiosas na Costa da Mina. Uma sistematização das fontes europeias pré-coloniais, 1600-1730. Disponível em: <http://www.costadamina.ufba.br/>.

Bibliografia:

ADAMS, John. Remarks on the Country from Cape Palmas to the River Congo, Including Observations on the Manners and Customs of the Inhabitants, with Appendix Containing an Account of the European Trade with the West Coast of Africa (1823). repr., Londres: Frank Cass and Co., 1966

BARBOT, Jean. Barbot on Guinea: The Writings of Jean Barbot on West Africa, 1678-1712 (organização de LAW, Robin; JONES, Adam; HAIR, Paul). Londres: Hakluyt Society, 1992. 
BARLÉU,Gaspar.OBrasilholandêssoboCondeMauríciodeNassau:história dos feitos recentemente praticados durante oito anos no Brasil e noutraspartes sobogovernodollustríssimo JoãoMaurícioCondede Nassau etc., ora Governador deWesel, Tenente-General de cavalaria das Províncias-Unidas Sob o Príncipe de Orange. Brasília: Senado Federal, 2005.

LABAT, Jean-Baptiste. Voyages du Chevalier des Marchais en Guinée, isles voisines et à Cayenne, fait em 1725, 1726 et 1727. Paris: Chez Saugrain, Quay de Gefvres, à la Croix Blanche, 1730, 2 vol.

JOHNSON, Samuel. The History of the Yorubas: From the Earliest Times to the Beginning of the British Protectorate. Lagos: CMS (Nigeria) Bookshop, 1956.

SANDOVAL, Alonso de. Naturaleza Policia, Sagrada i Profana, Costumes i Ritos, Disciplina e Catechismo Evangélico de Todos Etiopes por el PadreAlonsodeSandoval.Sevilha:Francisco de Lira Impressor, 1627. SMITH, William. A New Voyage to Guinea. Londres: Frank and Cass, 1967 [1744].

SNELGRAVE, William. ANew Account of Guinea, and the SlaveTrade[1734]. Londres: Frank Cass \& Co., 1971.

Referencias Bibliográficas:

AKINJOGBIN, I. A. Dahomey and its Neighbours, 1708-1818. Londres: Cambridge University Press, 1967.

ALENCASTRO, Luiz Felipe de. O trato dos viventes: formação do Brasil no AtlânticoSul, séculos XVleXVII.São Paulo:Companhia das Letras, 2000. .Desagravo de Pernambuco e a glória do Brasil:a obra de Evaldo Cabral de Mello. In: SCHWARCZ, Lilia Moritz (org.). Leituras críticas sobre Evaldo Cabral de Mello. Belo Horizonte: Editora da UFMG/SãoPaulo:EditoraFundaçãoPerseu Abramo, 2008, pp.35-55. ALMEIDA, Katia Lorena Novais. Escravos e libertos nas minas do Rio de Contas - Bahia, século XVIII. Tese (Doutorado em História Social). Faculdade de Filosofia e Ciências Humanas, Universidade Federal da Bahia, Bahia, 2012.

ANTONIL,AndréJoão.CulturaeOpulênciadoBrasilporsuasDrogaseMinas [1711]. Introdução e notas por SILVA, Andrée Mansuy Diniz. São Paulo: Editora da Universidade de São Paulo, 2007.

ARAÚJO, Ana Lucia. History, Memory and Imagination: Na Agontime, a Dahomean Queen in Brazil. In: FALOLA, Toyin; FWATSHAK, Sati U. (orgs.). Beyond Tradition: African Women and their Cultural Spaces. NJ: Africa World Press, 2011, pp. 45-65.

BAY, Edna. Wives of the Leopard: Gender, Politics, and Culture in the KingdomofDahomey.CharlottesvilleeLondres:UniversityofVirginia Press, 1998.

BOOGAART, Ernst van den; EMMER, Pieter C. The Dutch Participation in the Atlantic Slave Trade, 1596-1650. In: GEMERY, Henry A.; HOGENDORN, Jan S. (orgs.). The Uncommon Market: Essays in the Economic History of the Atlantic Slave Trade. Nova York: Academic Press, 1979, pp. 353-75

BOXER, Charles R. A idade de ouro do Brasil: dores de crescimento de uma sociedade colonial [1963]. Rio de Janeiro: Nova Fronteira, 2000.

.Oimpériomarítimoportuguês,1415-1825.SãoPaulo:Companhia 
das Letras, 2002.

CANDIDO, Mariana P. Fronteras de esclavización. Esclavitud, comercio e identidademBenguela, 1780-1850.México/DF:ElColegiodeMéxico, 2011.

. An African Slaving Port and the Atlantic World: Benguela and Its Hinterland. Nova York: Cambridge University Press, 2013.

CAPO, Hounkpati B.C. Comparative Phonology of Gbe. Berlin e Nova York: Foris Publications, 1991.

CAVALCANTI, Nireu. O comércio de escravos novos no Rio setecentista. In: FLORENTINO, Manolo (org.). Tráfico, cativeiro e liberdade (Rio de Janeiro - Séculos XVII-XIX). Rio de Janeiro: Civilização Brasileira, 2005, pp. 17-77.

CAVALCANTE, Paulo. Negócios de Trapaça: caminhos e descaminhos na América Portuguesa (1700-1750). São Paulo: Hucitec/FAPESP, 2006.

COSTA LIMA, Vivaldo da. A família de Santo nos candomblés jeje-nagôs da Bahia:umestudodas relaçõesintragrupais.Salvador:Corrupio,2003.

ELTIS, David. The Rise of African Slavery in the Americas. Nova York: Cambridge University Press, 2000.

. The Diaspora of Yoruba Speakers, 1650-1865. In: FALOLA, Toyin; CHILDS, Matt.TheYoruba Diaspora in the AtlanticWorld.Bloomington e Indianápolis: Indiana University Press, 2004, pp. 17-39.

ELTIS, David; RICHARDSON, David. Atlas of the Transatlantic Slave Trade. New Haven e Londres: Yale University Press, 2010.

In: A New Assessment of the Transatlantic Slave Trade. (orgs.). Extending the Frontiers: Essays on the New Transatlantic Slave Trade Database. New Haven e Londres: Yale University Press, 2008, p. 1-60.

ELTIS, David. Africa, Slavery, and the SlaveTrade, Mid-Seventeenth to MidEighteenth Centuries. In: CANNY, Nicholas; MORGAN, Philip (orgs.). The Oxford Handbook of the Atlantic World, 1450-1850. Oxford e Nova York: Oxford University Press, 2011, pp. 271-286.

ESPARTEIRO,VerAntónioMarques.PortugalnoDaomé(1471-1961).Lisboa: Agencia-Geral do Ultramar, 1961.

FARIA, Sheila de Castro. Sinhás Pretas, Damas Mercadoras: As pretas minas nas cidades do Rio de Janeiro e de São João Del Rey (1700-1850).Tese (Titular em História). Universidade Federal Fluminense, 2004.

FERREIRA, Roquinaldo Amaral.Transforming AtlanticSlaving:Trade,Warfare and Territorial Control in Angola, 1650-1800. Tese (Doutorado em História). University of California at Los Angeles, 2003.

. A arte de Furtar: redes de comércio ilegal no mercado imperial ultramarino português (ca. 1690-c. 1750). In: FRAGOSO, João; GOUVÊA, Maria de Fátima Silva (orgs.). Na Trama das redes: Política e Negócios no Império Português, séculos XVI-XVIII. Rio de Janeiro: Civilização Brasileira, 2010, pp. 203-243.

. From Brazil to West Africa: Dutch-Portuguese Rivalry, GoldSmuggling, and African Politics in the Bight of Benin (ca. 17001730). In: GROESEN, Michiel van (org.). The Legacy of Dutch Brazil. Nova York: Cambridge University Press, 2014, pp. 59-77.

FERRER, Ada. Freedom's Mirror: Cuba and Haiti in the Age of Revolution. Nova York: Cambridge University Press, 2015.

FLORENTINO,Manolo.Emcostasnegras:umahistóriadotráficodeescravos 
entre a África e o Rio de Janeiro: séculos XVIII e XIX. São Paulo:

Companhia das Letras, 1997.

FRAGOSO, João; Gouvêa, Maria de Fátima Silva. Nas rotas da governação portuguesa: Rio de Janeiroe Costa da Mina, séculoXVIII.In:FRAGOSO, João; FLORENTINO, Manolo; JUCÁ, Antônio Carlos; CAMPOS, Adriana (orgs.). Nas rotas do Império: eixo mercantis, tráfico e relações sociais no mundo português. $2^{\mathrm{a}}$. ed. Vitória: Edufes, 2014, pp. 23-66.

GEGGUS, David (org.). The Impact of the Haitian Revolution in the Atlantic World. Columbia: University of South Carolina Press, 2001.

GOMEZ, Michael A. Exchanging Our Country Marks: Transformations of Identities in the Colonial and Antebellum South. Chapel Hill: University of North Carolina Press, 1998.

. A quality of Anguish:The Igbo response to Enslavement in the Americas. In: LOVEJOY, Paul E.;TROTMAN, David V. (orgs.). TransAtlantic Dimensions of Ethnicity in the African Diaspora. Londres: Continuum Press, 2003, pp. 82-95.

GONSALVES de MELLO, José Antônio. Fontes para a História do Brasil Holandês (FHBH), vol. I. Recife: s.e., 1981.

HALL, Gwendolyn Midlo. Slavery and African Ethnicities in the Americas: Restoring the Links. Chapel Hill:University ofNorth CarolinaPress, 2005. . African Ethnicities and the Meanings of'Mina'. In: LOVEJOY, Paul; TROTMAN, DavidV. (orgs.).Trans-Atlantic Dimensions of Ethnicity in the African Diaspora. Londres: Continuum Press, 2003, pp. 65-81.

HARMS, Robert. The Diligent: A Voyage Through the Worlds of the Slave Trade. Nova York: Basic Books, 2002.

HERSKOVITS, Melville. Dahomey, an Ancient West African Kingdom. Nova York: J. J. Augustin, Publisher, 1938, 2 vol.

HOBSBAWM, Eric. A Era das Revoluções, 1789-1848. Rio de Janeiro: Paz e Terra, 2009 [1962].

JAMES, C. L. R. The Black Jacobins. Nova York: Vintage, 1963.

KARASCH, Mary C. A vida dos escravos no Rio de Janeiro (1808-1850). São Paulo: Companhia das Letras, 2000. .'Minha nação': identidades escravas no fim do Brasil Colonial. In: SILVA, Maria Beatriz Nizza da (org.). Brasil: colonização e escravidão. Rio de Janeiro: Nova Fronteira, 2000, pp. 27-41.

KLEIN, Herbert S. The Atlantic Slave Trade (New Approaches to the Americas). 2a . ed. Nova York: Cambridge University Press, 2010.

LAMPREIA, José D. Etno-História do Daomé. Subsídios para o seu estudo. Lisboa: Junta de Investigações do Ultramar, 1962.

LARA, SilviaHunold.Fragmentossetecentistas:escravidão, culturaepoder na América portuguesa. São Paulo: Companhia da Letras, 2007. .Linguagem, domíniosenhorial eidentidadeétnicanasMinas Gerais de meados do século XVIII. In: BASTOS, Cristiana Bastos; ALMEIDA, Miguel Vale de; FELDMAN-BIANCO, Bela (orgs.). Trânsitos Coloniais: diálogos críticos luso-brasileiros. Campinas: Editora da Unicamp, 2007, pp. 221-41.

LAST, Murray. The Sokoto Caliphate. Nova York: Humanities Press, 1967. LAW, Robin.TheSlaveCoastofWest Africa 1550-1750:The Impactofthe Atlantic Slave Trade on an African Society. Oxford: Oxford University Press, 1991. . Etnias de africanos na diáspora: novas considerações sobre os significados do termo'mina'Tempo, Rio de Janeiro, n²0, pp. 109-31, 2005. .The Oyo Empire, c. 1600-c. 1836: AWest African Imperialism in the 
Era of the Slave Trade. Oxford: Clarendon Press, 1977. . Ouidah:The Social History of a West African Slaving 'Port', 17271892. Athens: Ohio University Press, 2004. . The Kingdom of Allada. Leiden: Research School CNWS, 1997. . Ouidah as a Multi-Ethnic Community. In: CANIZARES-

ESGUERRA, Jorge; CHILDS, Matt; SIDBURY, James (orgs.). The Black Urban Atlantic in the Age of the SlaveTrade. Philadelphia:University of Pensilvania Press, 2013, pp. 42-62.

.The Gold Trade of Whydah in the Seventeenth and Eighteenth Centuries. In: HENIGE, David; McCASKIE, T. C. (orgs.). West African Economic and Social History:Studies in Memory of Marion Johnson. Wisconsin: African Studies Program/University of WisconsinMadison, 1990, pp. 105-18.

LE HERISSÉ, Auguste. L'Ancien royaume du Dahomey, moeurs, religion, histoire. Paris: Émile Larose, Libraire-Éditeur, 1911.

LOHSE, Kent Russell. AfricansandTheirDescendants in Colonial Costa Rica, 1600-1750. Tese (Doutorado em História). University of Texas at Austin, 2005.

. Africans into Creoles: Slavery, Ethnicity, and Identity in Colonial Costa Rica. Albuquerque: University of New Mexico Press, 2014.

LOPES, Edmundo Correia. A escravatura (subsídios para a sua história). Lisboa: Agência Geral das Colónias, 1944.

LOVEJOY, Paul E. Transformations in Slavery: A History of Slavery in Africa. 3a. ed. Nova York: Cambridge University Press, 2012. .(org.). Identity in the Shadow of Slavery.Londres:Continuum, 2000. ;TROTMAN, David V. (orgs.). Trans-Atlantic Dimensions of Ethnicity in the African Diaspora. Londres: Continuum Press, 2003. . Jihad e escravidão: as origens dos escravos muçulmanos da

Bahia. Topoi, Rio de Janeiro, v. 1, n. 1 (2000), pp. 11-44. .The Yoruba Factor in the Trans-Atlantic Slave Trade. In: FALOLA, Toyin; CHILDS, Matt. The Yoruba Diaspora in the Atlantic World. Bloomington e Indianápolis: Indiana University Press, 2004, p. 43, 44.

LOVEJOY, Paul E. Jihad na África Ocidental durante a"Era das Revoluções": em direção a um diálogo com Eric Hobsbawm e Eugene Genovese. Topoi, Rio de Janeiro, v. 15, n. 28, pp. 22-67. janeiro - junho de 2014.

MAIA, MoacirRodrigodeCastro.Oapadrinhamentodeafricanosem Minas Colonial:o (re)encontrona América (Mariana, 1715-1750). Afro-Ásia, 36, pp. 39-80, 2007.

MANNING, Patrick. Slavery and African Life: Occidental, Oriental, and African Slave Trades. Nova York: Cambridge University Press, 1990. .Slavery, ColonialismandEconomicGrowthinDahomey, 16401960. Cambridge: Cambridge University Press, 1982. . "The Slave Trade in the Bight of Benin, 1640-1890", In: GEMERY, Henry A. Gemery; HOGENDORN, Jan S. (orgs.). The Uncommon Market: Essays in the Economic History of the Atlantic Slave Trade. Nova York: Academic Press, 1979, pp. 107-141.

MATORY,J.Lorand.Jeje:repensando naçõesetransnacionalismo, Mana, $n^{\circ}$ 5, abr. 1999, pp. 57-80.

MELLO, Evaldo Cabral de. Olinda restaurada. Guerra e açúcar no nordeste, 1630-1654. São Paulo: Editora 34, 2007. O negócio do Brasil: Portugal, os Países Baixos e o Nordeste, 
1641-1669. São Paulo: Companhia das Letras, 2011.

MELLO eSOUZA, Laura de; REIS, João José. Popular Movements in Colonial

Brazil. In: CANNY, Nicholas; MORGAN, Philip. The Oxford Handbook of the Atlantic World, 1450-1850. Oxford e Nova York: Oxford University Press, 2011, pp. 550-566.

MORTON-WILLIAMS, Peter. The Oyo Yoruba and the Atlantic Trade, 1670-1830. In: INIKORI, J. E. (org.). Forced Migration: The Impact of the Export Slave Trade on African Societies. Londres: Hitchinson University Library, 1982, pp. 167-86.

NARDI, Jean Baptiste. O fumo brasileiro no período colonial: lavoura, comércio e administração. São Paulo: Brasiliense, 1996.

OLIVEIRA, Maria Inês Cortes de . Retrouver une identité: jeux sociaux des africains de Bahia (vers 1750-vers 1890). 1992. Tese (Doutorado em História). Université de Paris IV [Sorbonne], 1992.

.Quem eram os"Negros da Guiné"? A origem dos africanos na Bahia. Afro-Ásia, Salvador, n² 29/30 (1997), pp. 37-73. . Viver e morrer no meio dos seus: nações e comunidades africanas na Bahia do século XIX. Revista USP, n² 28, dez-fev. 19951996, pp. 174-193.

PARÉS, Luís Nicolau. A formação do Candomblé: história e ritual da nação jeje na Bahia. Campinas: Editora da Unicamp, 2006.

. Ethnic Religious Modes of Identificaton among the GbeSpeaking People in Eighteenth and Nineteenth Century Brazil. In: SANSONE, Lívio; SOUMONNI, Elisée; BARRY, Boubacar (orgs.). Africa, Braziland the Construction of Trans AtlanticBlack Identities.Trenton: Africa World Press, 2008, pp. 179-207.

POSTMA, Johannes.The Dutch in the AtlanticSlaveTrade, 1600-1815.Nova York: Cambridge University Press, 1990.

REID, Jonathan. Warfare in African History. Cambridge: Cambridge University Press, 2013.

REIS, João José. Rebelião escrava no Brasil: a história do levante dos malês em 1835. $2^{\mathrm{a}}$ ed. revista e ampliada. São Paulo: Companhia das Letras, 2003. . Magia Jeje na Bahia: a invasão do Calundu do Pasto de Cachoeira, 1785. Revista Brasileira de História, vol. 8ª n 16, pp. 5781, mar-ago. 1988.

RIBEIRO, Alexandre Vieira. O tráfico atlântico de escravos e a praça mercantil de Salvador, c. 1680-c. 1830. Dissertação (Mestrado em História Social). Universidade Federal do Rio de Janeiro, Rio de Janeiro, 2005.

RYDER, A. F.C. The Re-establishment of Portuguese Factories on the Costa da Mina to the Mid-Eighteenth Century. Journal of Historical Society of Nigeria, Vol. 1, No. 3, pp. 157-83, dezembro de 1958.

RODRIGUES, Raimundo Nina. Os africanos no Brasil. São Paulo: Editora Nacional; Brasília: Editora da Universidade de Brasília, 1982.

SANDOVAL, Alonso de. Un tratado sobre la esclavitud (introdução, transcrição e tradução de Enriqueta Vila Vilar). Madri: Alianza Editorial, 1987.

SCHWARTZ,StuartB.SegredosInternos:escravoseengenhosnasociedade colonial (1550 - 1835). São Paulo: Companhia das Letras, 1988. . Alforrias na Bahia, 1684-1745. In: . Escravos, roceiros e rebeldes. Bauru, SP: EDUSC, 2001, pp. 171-218.

SILVA, Daniel Barros Domingues da; ELTIS, David. The Slave Trade to 
Pernambuco, 1561-1851. In: ELTIS, David; RICHARDSON, David (orgs.). Extending the Frontiers: Essays on the New Transatlantic Slave Trade Database. New Haven eLondres:YaleUniversity Press, 2008, pp.95-129. SILVA JR., Carlos da. Identidades Afro-Atlânticas: Salvador, Século XVIII (1700-1750). Dissertação (Mestrado em História Social). Faculdade de Filosofia e Ciências Humanas, Universidade Federal da Bahia, Bahia, 2011.

. The Ports of the Bight of Benin and the Legal Slave Trade to Bahia, 1750-1815. In: Canadian Association of African Studies. Ottawa: Carleton University, maio de 2013.

SILVEIRA, Renato da. Nações africanas no Brasil escravista: problemas teóricos e metodológicos. Afro-Ásia, N. 38 p. 245-301, 2008.

SOARES, Mariza de Carvalho. Devotos da cor: identidade étnica, religiosidade e escravidão no Rio de Janeiro, século XVIII. Rio de Janeiro: Civilização Brasileira, 2000.

SOARES, Carlos Eugênio Líbano."Instruído na fé, batizado em pé": batismo de africanos na Sé da Bahia na primeira metade do século XVIII, 1734-1742. Afro-Ásia, 39 (2010), p. 79-113.

;GOMES, Flávio dos Santos; FARIAS, Juliana Barreto. No labirinto das nações: africanos e identidades no Rio de Janeiro, século XIX. Rio de Janeiro: Arquivo Nacional, 2005.

;SILVA JR., Carlos da.'Uma nova guiné': africanos em inventários e registros de batismo na cidade da Bahia da primeira metade do século XVIII. História Unisinos 14 (3), pp. 243-257, set./dez. 2010.

STABEN, Ana Emília. Negócio dos escravos: o comércio de cativos entre a CostadaMinaeaCapitaniadePernambuco(1701-1759).Dissertação (Mestrado em História). Universidade Federal do Paraná, Paraná, 2008.

TAVARES, António José Chrystêllo. Marcos fundamentais da presença portuguesa no Daomé. Lisboa: Universitária Editora, 1999.

THORNTON, John K. Africa and the Africans in the Making of the Atlantic World, $1400-1800.2^{\mathrm{a}}$.ed.ampliada.NovaYork:CambridgeUniversity Press, 1998.

. Warfare in Atlantic Africa, 1500-1800. Londres: UCL Press, 1999.

THORNTON, John K. A Cultural History of the Atlantic World, 1250-1820. Nova York: Cambridge University Press, 2012.

VERGER,Pierre.Fluxo erefluxo dotráfico deescravosentreoGolfo deBenin e a Bahia de Todos os Santos (dos séculos XVII a XIX). Salvador: Ed. Corrupio, $4^{a}$ ed., 2002 [1968]. . Notas sobre o culto aos orixás e voduns na Bahia de Todos os Santos, no Brasil, ena Antiga Costa dos Escravos, na África. São Paulo: Editora da Universidade de São Paulo, 2000.

. O fumo da Bahia e o tráfico de escravos do golfo do Benim.

Série Ensaios, №. 6. Salvador: Universidade Federal da Bahia, 1966. . Uma rainha africana mãe de santo em São Luís. Revista da USP, n. 6, pp. 151-58, agosto 1990

WAX, Darold D. Preferences for Slaves in Colonial America. The Journal of Negro History, vol. 58, n 4, pp. 371-401, outubro de 1973.

WIEDEMANN,Thomas.GreekandRomanSlavery.Londres:CroomHelmLtd,1981. 